\title{
Determination and Risk Assessment of Heavy Metals Concentrations collected from Indoor houses at Lagos State of Nigeria
}

\author{
Olawale Bamidele ${ }^{1}$, Ndokiari Boisa and Obunwo C.C $\mathbf{C}^{3}$ \\ ${ }^{1}$ Research scholar, ${ }^{2} \mathrm{Ph}$. D and ${ }^{3}$ Professor \\ Department of Chemistry, Rivers State University \\ PortHarcourt, Rivers State,
}

Nigeria

\begin{abstract}
The aim of this study is to determine the levels of selected heavy metals ( $\mathrm{As}, \mathrm{Pb}, \mathrm{Zn}, \mathrm{Cu}$ and $\mathrm{Cr}$ ) at 60 homes from the 20 local governments in Lagos State, Nigeria. Approval was sought from respective residential landlords and occupants of the sampled communities. Three dust samples were collected from each local government. A total of 60 dust samples were collected and labelled according to the first three letters of each Local government. Indoor dust samples from households (furniture, container bags, window slides, ceiling fan and standing fan) were collected using soft paint brushes. $0.5 \mathrm{~g}$ of the homogenized mixture was measured in triplicate labelled 1, 2 and 3 in different boiling tubes for digestion process. Each triplicate samples were digested using aqua regia for 1 hour at a temperature of about 100 degree celcius. Heavy metal concentrations were determined using Agilent Technologies 4210 MP-AES Atomic Absorption Spectrometer (AAS). The concentration of heavy metals in the indoor dust were dominated by Arsenic with an average concentration of 57.76-111.93 mg/kg followed Lead 13.81-116.60 mg/kg, Zinc 22.73$224.2 \mathrm{mg} / \mathrm{kg}$, Copper 8.27-228.75 $\mathrm{mg} / \mathrm{kg}$ and Chromium with concentration of 2.53-22.60 $\mathrm{mg} / \mathrm{kg}$ respectively. The concentrations of heavy metal in the areas investigated followed the order: $\mathrm{Ar}>\mathrm{Pb}>\mathrm{Zn}>\mathrm{Cu}>\mathrm{Cr}$. The exposure dose was also estimated through ingestion, inhalation and dermal contacts, and the exposure route was highest for ingestion pathway. The health risk (carcinogenic and non-carcinogenic) of these heavy metals were assessed based on the United States Environmental Protection Agency health risk models. The estimated values were compared to standard guidelines and human health limits by the United States Environmental Protection Agency, USEPA and California Environmental Protection Agency, Ca/EPA. For noncarcinogenic risk, the hazard index values for all the studied metals were lower than the safe level of 1 . The Total Lifetime Cancer Risk for adults and children were below the limit $\left(1 \times 10^{-6}-1 \times 10^{-4}\right)$ as standardized by USEPA except in children which was slightly

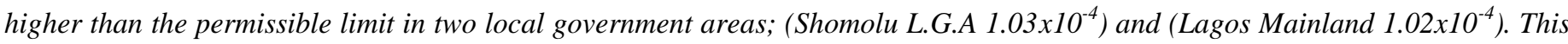
indicates that the risk of carcinogenic effect occurring is likely in children with exposure to arsenic
\end{abstract}

Key words: Lagos, Indoor dust, Heavy metals, Risk Assessment.

\section{INTRODUCTION}

A good air quality is important for the environment at large. Air is said to be polluted when it constitutes substances which can be harmful to the health of human, animals and vegetation. Polluted air causes life threatening diseases to man, animals and aquatic lives. Air pollution can be indoor or outdoor and has caused a significant problem worldwide. [1] defined dust as matter or particulate in the form of fine powder, lying on the ground or on the surface of objects or blown about by the wind. In 1997, Paustenbach in his publication, defined House dust as a heterogeneous mixture of substances from numerous sources, including tracked-in or resuspended soil particles, clothing, atmospheric deposition of particulates, hair, fibres (artificial and natural), molds, pollen, allergens, bacteria, viruses, arthropods, ash, soot, animal fur and dander, smoke, skin particles, cooking and heating residues, and building components among others [2]. The quality of indoor air is an environmental health concern as most people spend up to $85 \%$ of their time indoors in places, such as homes, offices and schools. Indoor settled dusts contain various hazardous materials including heavy metals, which can affect human health [3]. Heavy metals in indoor dust are an important indicator of pollution in urban environments [4]. Dust can be found as a suspension in the air or settled on surfaces. It originates 
from a number of sources including soil, abrasion of materials, pesticides, asbestors, pollen, bacteria, shed skin, cigarette smoke and dust mites [5].

Industrialization and large population in Lagos has led to the migration of people from one part to the other, in the process, generating thousands of tons of dust daily. The dust generated is expected to increase significantly in the near future as the state strives to attain an industrialized state status by the year 2020. Activities like the burning of local and assorted incenses, cooking with wood and other combusted fuels, burning of mosquito coils and application of aerosols as insect repellents indoor and outdoor also generate particulates and other pollutants such as organic compounds that may linger in the air or cling to dust particles.

Lagos is one of the 36 states in Nigeria. It is located on coordinates of $6^{0} 35^{\prime} \mathrm{N}$ and $3^{0} 45^{\prime} \mathrm{E}$ in the south-western part of Nigeria with an area of $3577 \mathrm{~km}^{2}$ and a population of approximately 20 million based on the 2006 Census. It is the smallest in area out of the Nigeria's 36 states. It is arguably the most economically important state of the country, if it were a country, it would be the fifth largest economy in Africa. It is bounded by Ogun State on the North and East. It shares boundaries with the Republic of Benin in the West. Just behind its southern borders lies the Atlantic.

Lagos is globally referred to as a megacity being a commercial and Industrial hub, with the presence of one of the largest and busiest parts in the world. Lagos state consist of 20 local government areas with Ikeja as the capital taking a significant 37 percent of the state's total land area. The 20 local governments contains two main divisions; Lagos mainland and Lagos Island and are Agege, Alimosho, Ifako Ijaiye, Ikeja, Kosofe, Mushin, Oshodi-Isolo, Ajeromi, Ojo, Ikorodu, Surulere, Shomolu, Amuwo-Odofin, Lagos Mainland, Eti-Osa, Badagry, Apapa, Lagos Island, Epe and Ibeju Lekki.

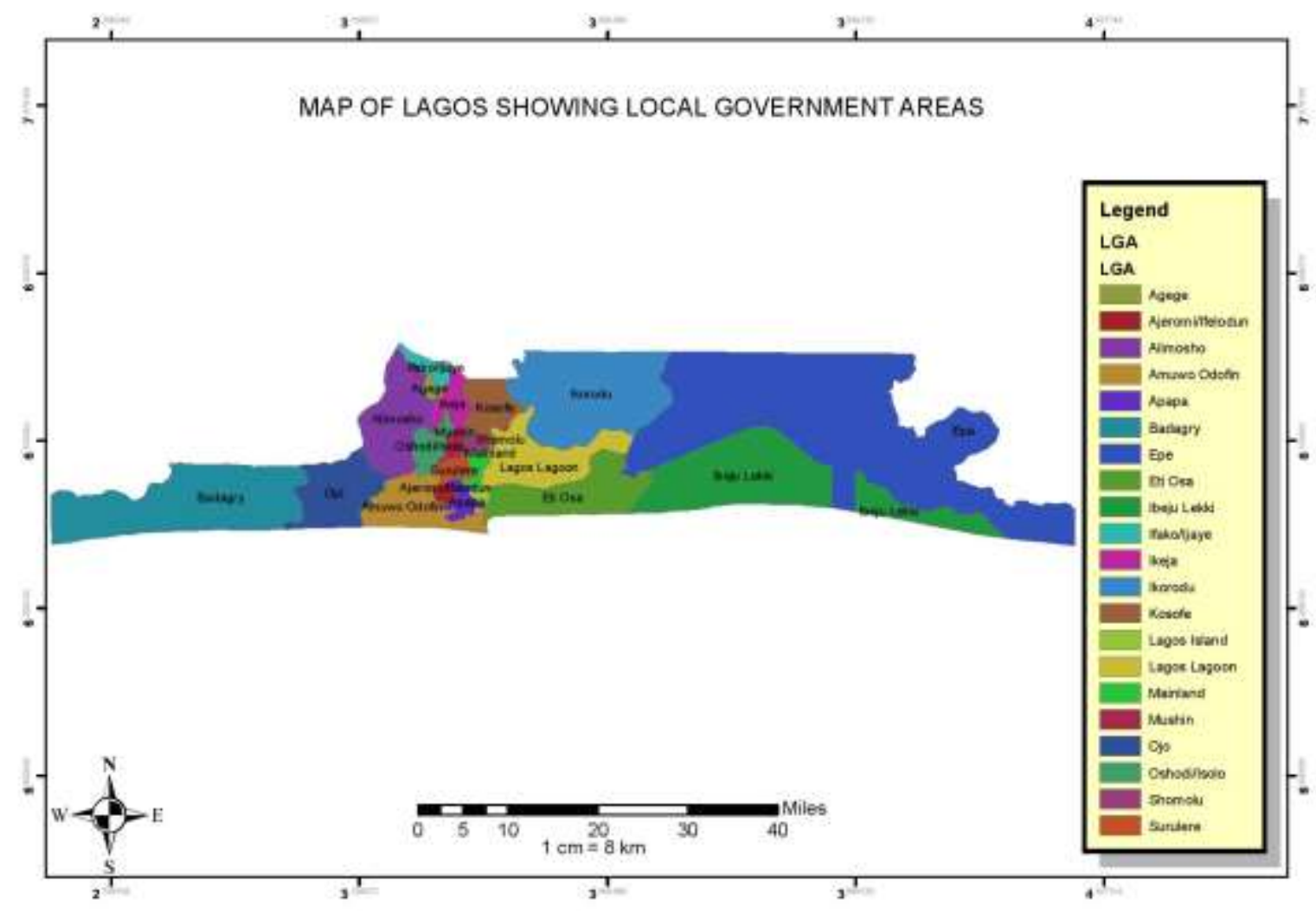

Fig 1.0 Lagos State map showing the 20 Local Government Areas

Presently in Lagos state, no published data is available for deposited and composition of indoor dust in households, including their composition. There is a need therefore to embark on studied focus on composition of the outdoor dust as well as indoor particles. This will highlight the possible risk to health of the Lagos State population.

The main objectives of the study are to

i Determine levels of iron, manganese cadmium, lead, chromium and arsenic in deposited indoor dust samples collected from the 20 Local government areas.

ii Compare the results of heavy metal concentrations with the values reported in past literatures

iii Assess the health risk of the selected heavy metals in children and adults 


\subsection{METHODOLOGY}

\subsection{Sampling Area}

Lagos is one of the 36 states in Nigeria. It is located on coordinates of $6^{0} 35^{\prime} \mathrm{N}$ and $3^{0} 45^{\prime} \mathrm{E}$ in the south-western part of Nigeria with an area of $3577 \mathrm{~km}^{2}$ and a population of approximately 20 million based on the 2006 Census. It is the smallest in area out of the Nigeria's 36 states. It is arguably the most economically important state of the country, if it were a country, it would be the fifth largest economy in Africa. It is bounded by Ogun State on the North and East. It shares boundaries with the Republic of Benin in the West. Just behind its southern borders lies the Atlantic.

\subsection{Sample Preparation and Methods}

\subsubsection{Sample Collection}

Approval was sought from respective residential Landlords and occupants of the sampled communities. Sampling was done between the month of January and March 2018. Samples were collected from all the 20 local Government Areas in Lagos state. Three dust samples were collected from each local government. A total of 60 dust samples were collected and labelled using the first three letters of each Local Government Areas. Samples were collected with the use of a paint brush into a plastic pan from items of furniture (desks, chairs), windows, fans, lamp covers, ceiling, standing and wall fans, window sills, cabinet tops and cleaner bags.

Table 1.0 Identification of Sampling Locations and Geographical Positions

\begin{tabular}{|c|c|c|c|}
\hline $\begin{array}{l}\text { LOCAL } \\
\text { GOVERNMENT }\end{array}$ & COMMUNITIES & CODE & $\begin{array}{l}\text { GEOGRAPHICAL } \\
\text { COORDINATES }\end{array}$ \\
\hline \multirow[t]{3}{*}{$\mathrm{OJO}$} & IJEODODO & OJO 1 & $6^{\circ} 29^{\prime} 40^{\prime \prime} \mathrm{N}, 3^{\circ} 15^{\prime} 18^{\prime \prime} \mathrm{E}$ \\
\hline & IGBO ELERIN & OJO 2 & $6^{\circ} 28^{\prime} 57^{\prime \prime} \mathrm{N}, 3^{\circ} 11^{\prime} 16^{\prime \prime} \mathrm{E}$ \\
\hline & IYANA IBA & OJO 3 & $6^{\circ} 27^{\prime} 57^{\prime \prime} \mathrm{N}, 3^{\circ} 12^{\prime} 14^{\prime \prime} \mathrm{E}$ \\
\hline \multirow[t]{3}{*}{ ALIMOSHO } & ALIMOSHO & ALM 1 & $6^{\circ} 37^{\prime} 07^{\prime \prime} \mathrm{N}, 3^{\circ} 17^{\prime} 49^{\prime \prime} \mathrm{E}$ \\
\hline & AYOBO-IPAJA & ALM 2 & $6^{\circ} 35^{\prime} 46^{\prime \prime} \mathrm{N}, 3^{\circ} 14^{\prime} 19^{\prime \prime} \mathrm{E}$ \\
\hline & IGANDO & ALM 3 & $6^{\circ} 33^{\prime} 23^{\prime \prime} \mathrm{N}, 3^{\circ} 16^{\prime} 05^{\prime \prime E}$ \\
\hline \multirow[t]{3}{*}{ IFAKO-IJAIYE } & ALAKUKO & FKJ 1 & $6^{\circ} 41^{\prime} 10^{\prime \prime} \mathrm{N}, 3^{\circ} 15^{\prime} 43^{\prime \prime} \mathrm{E}$ \\
\hline & EKORO JUNCTION & FKJ 2 & $6^{\circ} 38^{\prime} 35^{\prime \prime} \mathrm{N}, 3^{\circ} 17^{\prime} 18^{\prime \prime} \mathrm{E}$ \\
\hline & ABORU & FKJ 3 & $6^{\circ} 38^{\prime} 04^{\prime \prime} \mathrm{N}, 3^{\circ} 17^{\prime} 01^{\prime \prime} \mathrm{E}$ \\
\hline \multirow[t]{3}{*}{ IKORODU } & ODONGUNYAN & KRD 1 & $6^{\circ} 42^{\prime} 02^{\prime \prime} \mathrm{N}, 3^{\circ} 25^{\prime} 40^{\prime \prime} \mathrm{E}$ \\
\hline & AGRIC & KRD 2 & $6^{\circ} 37^{\prime} 28^{\prime \prime} \mathrm{N}, 3^{\circ} 28^{\prime} 31^{\prime \prime E}$ \\
\hline & IMOTA & KRD 3 & $6^{\circ} 39^{\prime} 07^{\prime \prime} \mathrm{N}, 3^{\circ} 38^{\prime} 22^{\prime \prime} \mathrm{E}$ \\
\hline \multirow[t]{3}{*}{ OSHODI } & CGAC IYANA ISOLO & OSHO 1 & $6^{\circ} 32^{\prime} 10^{\prime \prime} \mathrm{N}, 3^{\circ} 19^{\prime} 48^{\prime \prime E}$ \\
\hline & MAFOLUKU & OSHO 2 & $6^{\circ} 32^{\prime} 53^{\prime \prime} \mathrm{N}, 3^{\circ} 21^{\prime} 08^{\prime \prime} \mathrm{E}$ \\
\hline & AJAO ESTATE & OSHO 3 & $6^{\circ} 33^{\prime} 22^{\prime \prime} \mathrm{N}, 3^{\circ} 19^{\prime} 42^{\prime \prime E}$ \\
\hline \multirow[t]{3}{*}{ AGEGE } & PEN CINEMA & AGG 1 & $6^{\circ} 37^{\prime} 56^{\prime \prime} \mathrm{N}, 3^{\circ} 20^{\prime} 28^{\prime \prime} \mathrm{E}$ \\
\hline & OGBA & AGG 2 & $6^{\circ} 37^{\prime} 11^{\prime \prime} \mathrm{N}, 3^{\circ} 19^{\prime} 51^{\prime \prime E}$ \\
\hline & ORILE & AGG 3 & $6^{\circ} 40^{\prime} 37^{\prime \prime} \mathrm{N}, 3^{\circ} 17^{\prime} 40^{\prime \prime} \mathrm{E}$ \\
\hline \multirow[t]{3}{*}{ IBEJU-LEKKI } & AJAH & IBJ 1 & $6^{\circ} 25^{\prime} 22^{\prime \prime} \mathrm{N}, 3^{\circ} 42^{\prime} 39^{\prime \prime} \mathrm{E}$ \\
\hline & AWOYAYA & IBJ 2 & $6^{\circ} 28^{\prime} 27^{\prime \prime} \mathrm{N}, 3^{\circ} 42^{\prime} 29^{\prime \prime} \mathrm{E}$ \\
\hline & ILAJE & IBJ 3 & $6^{\circ} 27^{\prime} 50^{\prime \prime} \mathrm{N}, 3^{\circ} 33^{\prime} 41^{\prime \prime E}$ \\
\hline \multirow[t]{3}{*}{ BADAGRY } & AGBARA & BDG 1 & $6^{\circ} 30^{\prime} 20^{\prime \prime} \mathrm{N}, 3^{\circ} 06^{\prime} 05^{\prime \prime E}$ \\
\hline & OKO-AFO & BDG 2 & $6^{\circ} 29^{\prime} 12^{\prime \prime} \mathrm{N}, 3^{\circ} 01^{\prime} 45^{\prime \prime E}$ \\
\hline & IBEREKO & BDG 3 & $6^{\circ} 18^{\prime} 18^{\prime \prime} \mathrm{N}, 3^{\circ} 01^{\prime} 30^{\prime \prime} \mathrm{E}$ \\
\hline \multirow[t]{3}{*}{ SHOMOLU } & DUROSIMI & SHM 1 & $6^{\circ} 31^{\prime} 59^{\prime \prime} \mathrm{N}, 3^{\circ} 22^{\prime} 12^{\prime \prime} \mathrm{E}$ \\
\hline & SALVATION ARMY & SHM 2 & $6^{\circ} 32^{\prime} 01^{\prime \prime} \mathrm{N}, 3^{\circ} 22^{\prime} 09^{\prime \prime E}$ \\
\hline & CENTRAL MOSQUE & SHM 3 & $6^{\circ} 32^{\prime} 07^{\prime \prime} \mathrm{N}, 3^{\circ} 22^{\prime} 19^{\prime \prime} \mathrm{E}$ \\
\hline \multirow[t]{3}{*}{ LAGOS MAINLAND } & MAKOKO & LSM 1 & $6^{\circ} 29^{\prime} 44^{\prime \prime} \mathrm{N}, 3^{\circ} 23^{\prime} 09^{\prime \prime} \mathrm{E}$ \\
\hline & EBUTTE META & LSM 2 & $6^{\circ} 29^{\prime} 18^{\prime \prime} \mathrm{N}, 3^{\circ} 22^{\prime} 38^{\prime \prime E}$ \\
\hline & ST FINBARS AKOKA & LSM 3 & $6^{\circ} 31^{\prime} 18^{\prime \prime} \mathrm{N}, 3^{\circ} 23^{\prime} 12^{\prime \prime} \mathrm{E}$ \\
\hline \multirow[t]{2}{*}{ MUSHIN } & OLATEJU & MSH 1 & $6^{\circ} 31^{\prime} 57^{\prime \prime} \mathrm{N}, 3^{\circ} 21^{\prime} 28^{\prime \prime} \mathrm{E}$ \\
\hline & ITIRE & MSH 2 & $6^{\circ} 31^{\prime} 13^{\prime \prime} \mathrm{N}, 3^{\circ} 20^{\prime} 45^{\prime \prime E}$ \\
\hline
\end{tabular}


International Journal of Advances in Scientific Research and Engineering (ijasre), Vol 6 (3), March -2020

\begin{tabular}{|c|c|c|c|}
\hline & KELANI & MSH 3 & $6^{\circ} 31^{\prime} 35^{\prime \prime} \mathrm{N}, 3^{\circ} 21^{\prime} 23^{\prime \prime} \mathrm{E}$ \\
\hline \multirow[t]{3}{*}{ APAPA } & IJORA & APP 1 & $6^{\circ} 33^{\prime} 54^{\prime \prime} \mathrm{N}, 3^{\circ} 19^{\prime} 03^{\prime \prime} \mathrm{E}$ \\
\hline & KIRIKIRI & APP 2 & $6^{\circ} 26^{\prime} 42^{\prime \prime} \mathrm{N}, 3^{\circ} 18^{\prime} 26^{\prime \prime} \mathrm{E}$ \\
\hline & BEACH LAND ESTATE & APP 3 & $6^{\circ} 26^{\prime} 33^{\prime \prime} \mathrm{N}, 3^{\circ} 19^{\prime} 20^{\prime \prime} \mathrm{E}$ \\
\hline \multirow[t]{3}{*}{ AMUWO-ODOFIN } & $1^{\text {ST }}$ AVENUE & AMU 1 & $6^{\circ} 28^{\prime} 15^{\prime \prime} \mathrm{N}, 3^{\circ} 17^{\prime} 42^{\prime \prime} \mathrm{E}$ \\
\hline & K CLOSE $7^{\mathrm{TH}}$ AVENUE & AMU 2 & $6^{\circ} 28^{\prime} 08^{\prime \prime} \mathrm{N}, 3^{\circ} 16^{\prime} 14^{\prime \prime} \mathrm{E}$ \\
\hline & $2^{\mathrm{ND}}$ AVENUE & AMU 3 & $6^{\circ} 28^{\prime} 17^{\prime \prime} \mathrm{N}, 3^{\circ} 16^{\prime} 22^{\prime \prime} \mathrm{E}$ \\
\hline \multirow[t]{3}{*}{ EPE } & MAGBON & EPE 1 & $6^{\circ} 36^{\prime} 36^{\prime \prime} \mathrm{N}, 3^{\circ} 56^{\prime} 46^{\prime \prime} \mathrm{E}$ \\
\hline & IBEJU & EPE 2 & $6^{\circ} 36^{\prime} 07^{\prime \prime} \mathrm{N}, 3^{\circ} 56^{\prime} 32^{\prime \prime} \mathrm{E}$ \\
\hline & MEJINDADE CLOSE & EPE 3 & $6^{\circ} 36^{\prime} 44^{\prime \prime} \mathrm{N}, 3^{\circ} 57^{\prime} 04^{\prime \prime} \mathrm{E}$ \\
\hline \multirow[t]{3}{*}{ IKEJA } & OBA AKRAN & IKJ 1 & $6^{\circ} 36^{\prime} 29^{\prime \prime} \mathrm{N}, 3^{\circ} 20^{\prime} 12^{\prime \prime} \mathrm{E}$ \\
\hline & OPEBI LINK ROAD & IKJ 2 & $6^{\circ} 33^{\prime} 50^{\prime \prime} \mathrm{N}, 3^{\circ} 19^{\prime} 48^{\prime \prime} \mathrm{E}$ \\
\hline & SECRETARIAT & IKJ 3 & $6^{\circ} 36^{\prime} 38^{\prime \prime} \mathrm{N}, 3^{\circ} 21^{\prime} 20^{\prime \prime} \mathrm{E}$ \\
\hline \multirow[t]{3}{*}{ ETI-OSA } & LEKKI PHASE 1 & ETI 1 & $6^{\circ} 26^{\prime} 41^{\prime \prime} \mathrm{N}, 3^{\circ} 24^{\prime} 30^{\prime \prime} \mathrm{E}$ \\
\hline & IKOYI & ETI 2 & $6^{\circ} 26^{\prime} 53^{\prime \prime} \mathrm{N}, 3^{\circ} 21^{\prime} 40^{\prime \prime} \mathrm{E}$ \\
\hline & VICTORIA ISLAND & ETI 3 & $6^{\circ} 26^{\prime} 07^{\prime \prime} \mathrm{N}, 3^{\circ} 25^{\prime} 04^{\prime \prime} \mathrm{E}$ \\
\hline \multirow[t]{3}{*}{ LAGOS ISLAND } & MARINA & LSD 1 & $6^{\circ} 26^{\prime} 56^{\prime \prime} \mathrm{N}, 3^{\circ} 23^{\prime} 00^{\prime \prime} \mathrm{E}$ \\
\hline & CMS & LSD 2 & $6^{\circ} 27^{\prime} 22^{\prime \prime} \mathrm{N}, 3^{\circ} 23^{\prime} 30^{\prime \prime} \mathrm{E}$ \\
\hline & APONGBON & LSD 3 & $6^{\circ} 27^{\prime} 27^{\prime \prime} \mathrm{N}, 3^{\circ} 22^{\prime} 32^{\prime \prime} \mathrm{E}$ \\
\hline \multirow[t]{3}{*}{ KOSOFE } & OGUDU & KSF 1 & $6^{\circ} 34^{\prime} 26^{\prime \prime} \mathrm{N}, 3^{\circ} 23^{\prime} 47^{\prime \prime} \mathrm{E}$ \\
\hline & MILE 12 & KSF 2 & $6^{\circ} 36^{\prime} 34^{\prime \prime} \mathrm{N}, 3^{\circ} 23^{\prime} 57^{\prime \prime} \mathrm{E}$ \\
\hline & DEEPER LIFE & KSF 3 & $6^{\circ} 36^{\prime} 00^{\prime \prime} \mathrm{N}, 3^{\circ} 23^{\prime} 57^{\prime \prime} \mathrm{E}$ \\
\hline \multirow[t]{3}{*}{ AJEROMI } & AMUKOKO & AJE 1 & $6^{\circ} 28^{\prime} 12^{\prime \prime} \mathrm{N}, 3^{\circ} 20^{\prime} 33^{\prime \prime} \mathrm{E}$ \\
\hline & SURU ALABA & AJE 2 & $6^{\circ} 27^{\prime} 46^{\prime \prime} \mathrm{N}, 3^{\circ} 19^{\prime} 28^{\prime \prime} \mathrm{E}$ \\
\hline & AWODIORA ESTATE & AJE 3 & $6^{\circ} 27^{\prime} 07^{\prime \prime} \mathrm{N}, 3^{\circ} 19^{\prime} 26^{\prime \prime} \mathrm{E}$ \\
\hline \multirow[t]{3}{*}{ SURULERE } & SHITTA & SRL 1 & $6^{\circ} 29^{\prime} 57^{\prime \prime} \mathrm{N}, 3^{\circ} 21^{\prime} 31^{\prime \prime E}$ \\
\hline & BODE THOMAS & SRL 2 & $6^{\circ} 29^{\prime} 19^{\prime \prime} \mathrm{N}, 3^{\circ} 21^{\prime} 30^{\prime \prime} \mathrm{E}$ \\
\hline & OJUELEGBA & SRL 3 & $6^{\circ} 30^{\prime} 34^{\prime \prime} \mathrm{N}, 3^{\circ} 21^{\prime} 54^{\prime \prime} \mathrm{E}$ \\
\hline
\end{tabular}

\subsubsection{Sample Preparation}

The 3 dust samples from each local Government Areas were mixed to have a composite sample and screened to remove any visible hair, soil, and grit. The samples were then air dried for 7 days and homogenized using a mortar and pestle. The samples were sieved through $1 \mathrm{~mm}$ mesh sieve to remove small stones. $0.5 \mathrm{~g}$ of the homogenized mixture was measured in triplicate labelled 1, 2 and 3 in different boiling tubes for digestion process.

\subsubsection{Sample Digestion and Metal Analysis}

Dust samples were digested in a fume cupboard. Each triplicate samples was digested using aqua regia for 1 hour at a temperature of about 100 degrees celcius. The outcome mixture was filtered using Whatman No. 42 Filter paper. The filtrate was made up to $50 \mathrm{~mL}$ with distilled water and stored in plastic bottles until analysis. Heavy metal concentrations were determined using Agilent Technologies 4210 MP-AES Atomic Absorption Spectrometer (AAS).

\subsubsection{Mapping}

Maps representing concentration were generated for each metal across all Local government using Digital mapping by Land referencing services.

\subsubsection{Health Risk Assessment}

The method used in calculating the exposure of children and adults to metals in dust is as described by [6], based on the models developed by US Environmental Protection Agency [7]. Children are exposed to dust through three main pathways: ingestion of dust, inhalation of dust particles through mouth and nose, and dermal contact ([8], [9]). Receiver of the dose through these three paths was estimated by USEPA, ([10], [7]) as described thus;

$D_{\text {ing }}=\mathrm{C} \times($ IngR $\times$ EF $\times$ ED $) \times 10^{-6}$

BW x AT

$\mathrm{D}_{\text {inh }}=\mathrm{C} \times(\operatorname{InhR} \times \mathrm{EF} \times \mathrm{ED})$ 
International Journal of Advances in Scientific Research and Engineering (ijasre), Vol 6 (3), March -2020

PEF x BW x AT

$D_{\text {dermal }}=C \times$ SA $\times$ SL $\times$ ABS $\times$ EF $\times$ ED) $\times 10^{-6}$

BW $x \quad$ AT

Where;

$\mathrm{C}$ is the concentration in $\mathrm{mgkg}^{-1}$ of metal in indoor dust

$\mathrm{D}\left(\mathrm{mgkg}^{-1} \mathrm{day}^{-1}\right)$ is the dose contacted through ingestion $\left(\mathrm{D}_{\text {ing }}\right)$, inhalation $\left(\mathrm{D}_{\text {ing }}\right)$ and dermal contact $\left(\mathrm{D}_{\text {dermal }}\right)$

IngR is the ingestion rate, taken to be $200 \mathrm{mgday}^{-1}$ for children and $100 \mathrm{mgday}^{-1}$ for adults according to USEPA ,[11]

InhR is the inhalation rate which was taken as $7.6 \mathrm{~m}^{3} \mathrm{day}^{-1}$ for the children and $20 \mathrm{~m}^{3} \mathrm{day}^{-1}$ for adults [12].

EF is the exposure relative frequency $\left(\right.$ dayyear $\left.{ }^{-1}\right)$, taken as 180 days per year [13].

ED is the exposure duration in years, taken as 6years for children and 24years for adults [14]

SA is the exposed skin area in $\mathrm{cm}^{2}$, and was assumed to be $2800 \mathrm{~cm}^{2}$ for children and $5700 \mathrm{~cm}^{2}$ for adults [14].

$\mathrm{SL}$ is the skin adherence factor in $\mathrm{mgcm}^{2} \mathrm{day}^{-1}$. In this study, SL was assumed to be $0.2 \mathrm{mgcm}^{-2} \mathrm{day}^{-1}$ for children and $0.7 \mathrm{mgcm}$ ${ }^{2}$ day $^{-1}$ for adults [14].

$\mathrm{ABS}$ is the dermal factor, which was taken to be 0.001 for all elements except arsenic which ABS equals 0.03 [15]

PEF is the particle emission factor, which in this study was given as $1.36 \times 10^{9} \mathrm{~m}^{3} \mathrm{~kg}^{-1}[11]$

BW is the average body weight. In this study, $15 \mathrm{~kg}$ was taken for children and 70kg for adults [14].

AT is the averaging time given in days. It is calculated thus; ED $\times 365$ days for non-carcinogens and $70 \times 365$ days for carcinogens.

i. Hazard Quotient (HQ) or Non-Cancer Risk

This was calculated by dividing the average daily dose derived for each element and exposure pathway by the metal corresponding reference dose (RfD) in $\mathrm{mgkg}^{-1} \mathrm{day}^{-1}$, given thus;

$\mathrm{HQ}=\underline{\mathrm{DD}}$

RfD

$\mathrm{HQ}=$ Hazard quotient or Non-cancer risk

$\mathrm{DD}=$ Average Daily Dose which may be $\mathrm{D}_{\text {ing }}, \mathrm{D}_{\text {inh }}, \mathrm{D}_{\text {dermal }}$

The hazard index $(\mathrm{HI})$ is equal to the summation of $\mathrm{HQs}$ of the three exposure pathways, $\mathrm{HI}=\mathrm{HQ}_{\text {ing }}+\mathrm{HQ}_{\text {inh }}+\mathrm{HQ}_{\text {dermal, }}$ i.e., the total hazard quotient (HQ) of the three exposure pathways (ingestion, inhalation and dermal contact) ([16],[9]).

Where;

$\mathrm{HQ}_{\text {ing }}$ is the Hazard quotient for total ingestion

$\mathrm{HQ}_{\text {inh }}$ is the Hazard quotient for total inhalation

$\mathrm{HQ}_{\text {dermal }}$ is the Hazard quotient for total dermal

If $\mathrm{HI}<1$, it is believed that there is chance that non-carcinogenic effects may occur, with a probability which tends to increase as $\mathrm{HI}$ increases.

ii. Carcinogenic Risk

This is the probability of an individual developing any type of cancer from lifetime exposure to carcinogenic hazards [6]. The carcinogenic risk is represented by LCR which is calculated by multiplying the Average Daily Dose by the corresponding slope factor (SF).

$\mathrm{LCR}=\mathrm{ADD} \times \mathrm{SF}$

Where;

LCR = Lifetime Carcinogenic Risk

$\mathrm{ADD}=$ Average Daily Dose

$\mathrm{SF}=$ Slope factor

Total Lifetime Carcinogenic Risk is calculated by the addition of all the LCRs calculated for ingestion, inhalation and dermal.

$\mathrm{TLCR}=\mathrm{LCR}_{\text {ing }}+\mathrm{LCR}_{\text {inh }}+\mathrm{LCR}_{\text {dermal }}$ 
International Journal of Advances in Scientific Research and Engineering (ijasre), Vol 6 (3), March -2020

The tolerable or acceptable risk for regulatory purposes is in the range $10^{-6}-10^{-4}[6]$. This however implies that if the given range is exceeded, carcinogenic risk is most likely to occur over time.

Table 2.0 Reference Dose and Cancer Slope Factors for Metals

\begin{tabular}{llllll}
\hline & As & $\mathbf{C r}$ & $\mathbf{C u}$ & $\mathbf{P b}$ & $\mathbf{Z n}$ \\
\hline $\mathbf{R f D}_{\text {ing }}$ & $3.00 \times 10^{-4}$ & $3.00 \times 10^{-3}$ & $4.00 \times 10^{-2}$ & $3.50 \times 10^{-3}$ & $3.00 \times 10^{-1}$ \\
$\mathbf{R f D}_{\text {inh }}$ & $3.01 \times 10^{-4}$ & $2.86 \times 10^{-5}$ & $4.02 \times 10^{-2}$ & $3.52 \times 10^{-3}$ & $3.00 \times 10^{-1}$ \\
$\mathbf{R f D}_{\text {dermal }}$ & $1.23 \times 10^{-4}$ & $6.00 \times 10^{-5}$ & $1.20 \times 10^{-2}$ & $5.25 \times 10^{-4}$ & $6.00 \times 10^{-2}$ \\
$\mathbf{S F}$ & $1.51 \times 10^{1}$ & $4.20 \times 10^{1}$ & & & \\
\hline
\end{tabular}

\section{RESULTS AND DISCUSSION}

The mean and standard deviation concentration of all the elements ( $\mathrm{As}, \mathrm{Cd}, \mathrm{Cr}, \mathrm{Pb}$ and $\mathrm{Zinc}$ ) in all the 20 local government areas in Lagos state were calculated. Table 3.0 shows the mean concentration of each metal across local governments.

Table 3.0 Mean Concentration of all metals ( $\mathrm{As}, \mathrm{Zn}, \mathrm{Cu}, \mathrm{Pb}$ and $\mathrm{Cr}$ ) in the whole Local Government Areas

\begin{tabular}{|c|c|c|c|c|c|}
\hline $\begin{array}{l}\text { LOCAL GOVT } \\
\text { AREA }\end{array}$ & $\begin{array}{l}\text { Mean } \\
\text { concentration of } \\
\text { As }\end{array}$ & $\begin{array}{l}\text { Mean } \\
\text { concentration of } \\
\text { Zn }\end{array}$ & $\begin{array}{l}\text { Mean } \\
\text { concentration of } \\
\mathrm{Cu}\end{array}$ & $\begin{array}{l}\text { Mean } \\
\text { concentration of } \\
\text { Pb }\end{array}$ & $\begin{array}{l}\text { Mean } \\
\text { concentration of } \\
\mathrm{Cr}\end{array}$ \\
\hline OSHODI & $101.73 \pm 2.76$ & $51.93 \pm 2.27$ & $16.13 \pm 0.31$ & $84.73 \pm 0.50$ & $11.20 \pm 1.04$ \\
\hline AGEGE & $107.13 \pm 9.45$ & $22.73 \pm 0.99$ & $10.60 \pm 0.00$ & $72.40 \pm 1.06$ & $8.80 \pm 0.00$ \\
\hline IBEJU LEKKI & $103.27 \pm 6.72$ & $26.93 \pm 4.97$ & $13.93 \pm 3.93$ & $78.27 \pm 3.78$ & $4.47 \pm 0.42$ \\
\hline BADAGRY & $86.00 \pm 13.17$ & $31.40 \pm 2.09$ & $19.40 \pm 2.08$ & $117.00 \pm 5.74$ & $22.60 \pm 2.96$ \\
\hline SHOMOLU & $111.93 \pm 3.14$ & $27.47 \pm 2.89$ & $19.47 \pm 6.29$ & $80.00 \pm 0.35$ & $6.80 \pm 0.35$ \\
\hline LAGOS & $110.80 \pm 5.39$ & $14.40 \pm 0.92$ & $8.27 \pm 0.81$ & $77.93 \pm 0.76$ & $2.53 \pm 0.58$ \\
\hline \multicolumn{6}{|l|}{ MAINLAND } \\
\hline MUSHIN & $93.60 \pm 10.41$ & $93.80 \pm 18.41$ & $23.07 \pm 5.77$ & $129.87 \pm 16.36$ & $11.07 \pm 1.79$ \\
\hline APAPA & $107.40 \pm 8.93$ & $169.53 \pm 1.33$ & $17.00 \pm 1.91$ & $85.73 \pm 0.76$ & $14.00 \pm 0.35$ \\
\hline IFAKO IJAIYE & $106.27 \pm 1.01$ & $29.87 \pm 7.41$ & $168.22 \pm 12.97$ & $75.47 \pm 0.50$ & $6.47 \pm 0.31$ \\
\hline IKORODU & $106.27 \pm 1.97$ & $36.60 \pm 5.54$ & $17.13 \pm 3.23$ & $81.27 \pm 1.47$ & $10.53 \pm 2.72$ \\
\hline AMUWO & $104.27 \pm 2.14$ & $25.47 \pm 2.55$ & $11.27 \pm 0.81$ & $78.47 \pm 0.83$ & $7.13 \pm 0.92$ \\
\hline \multicolumn{6}{|l|}{ ODOFIN } \\
\hline EPE & $106.27 \pm 4.69$ & $139.27 \pm 34.07$ & $14.87 \pm 3.23$ & $84.27 \pm 2.72$ & $16.67 \pm 5.83$ \\
\hline IKEJA & $105.00 \pm 1.93$ & $20.60 \pm 2.12$ & $18.60 \pm 3.82$ & $79.07 \pm 5.72$ & $9.07 \pm 0.31$ \\
\hline OJO & $105.13 \pm 1.70$ & $20.53 \pm 1.40$ & $10.67 \pm 0.23$ & $73.60 \pm 0.20$ & $8.80 \pm 0.53$ \\
\hline ETI-OSA & $57.76 \pm 36.60$ & $11.57 \pm 2.92$ & $20.10 \pm 8.03$ & $13.81 \pm 1.68$ & $10.13 \pm 0.99$ \\
\hline LAGOS ISLAND & $104.33 \pm 4.23$ & $16.60 \pm 4.36$ & $15.53 \pm 4.97$ & $75.93 \pm 1.42$ & $5.53 \pm 1.50$ \\
\hline KOSOFE & $101.33 \pm 5.60$ & $39.93 \pm 3.67$ & $17.67 \pm 4.24$ & $84.60 \pm 4.42$ & $8.00 \pm 0.35$ \\
\hline AJEROMI & $99.80 \pm 3.90$ & $74.20 \pm 2.51$ & $14.67 \pm 0.31$ & $116.60 \pm 1.31$ & $11.80 \pm 0.20$ \\
\hline SURULERE & $97.80 \pm 2.99$ & $224.2 \pm 9.07$ & $76.07 \pm 1.61$ & $66.47 \pm 12.24$ & $20.6 \pm 1.84$ \\
\hline ALIMOSHO & $98.27 \pm 5.32$ & $33.73 \pm 8.49$ & $16.87 \pm 4.56$ & $85.60 \pm 3.17$ & $11.60 \pm 1.56$ \\
\hline
\end{tabular}

\subsection{Heavy Metals Concentration in Indoor Dust}

The concentrations of $\mathrm{As}, \mathrm{Pb}, \mathrm{Zn}, \mathrm{Cu}$ and $\mathrm{Cr}$ in the indoor dust samples from the 20 Local governments Areas were presented in Table 4.6. Arsenic, was recorded as having the highest concentration among the heavy metals analysed, with an average concentration of $102.89 \mathrm{mg} / \mathrm{kg}$ followed by $\mathrm{Pb}(85.77 \mathrm{mg} / \mathrm{kg}), \mathrm{Zn}(54.04 \mathrm{mg} / \mathrm{kg}), \mathrm{Cu}(25.37 \mathrm{mg} / \mathrm{kg})$ and $\mathrm{Cr}(9.23 \mathrm{mg} / \mathrm{kg})$. 
Arsenic concentration across the local government areas ranged from $86.60 \mathrm{mg} / \mathrm{kg}-111.93 \mathrm{mg} / \mathrm{kg}$ with Badagry having the lowest and Shomolu having the highest concentration. Only five local governments have less than $100 \mathrm{mg} / \mathrm{kg}$ concentration of Arsenic. They include Badagry ( $86.00 \mathrm{mg} / \mathrm{kg}$ ), Mushin $(93.60 \mathrm{mg} / \mathrm{kg})$, Ajeromi (99.80 mg/kg), Surulere (97.80) and Alimosho (98.27 mg/kg). [17] reported the concentration of Arsenic to range from $24 \mathrm{mg} / \mathrm{kg}-3740 \mathrm{mg} / \mathrm{kg}$ and $33 \mathrm{mg} / \mathrm{kg}-1160 \mathrm{mg} / \mathrm{kg} \mathrm{in} \mathrm{two}$ separate mining locations. The concentration of Arsenic previously reported for abandoned mine site by [18]as well as (2006) [19] were $1 \mathrm{mg} / \mathrm{kg}-330 \mathrm{mg} / \mathrm{kg}$, and $43-486 \mathrm{mg} / \mathrm{kg}$ respectively. In comparison with the earlier literatures, the high concentrations observed for Lagos State in this study may be due to the high rate of combustion of wastes in the metropolis. The presence of Arsenic from this study may also be due to large population [20]. The concentrations of arsenic were well above the Ca/EPA screening level $\left(0.07 \mathrm{mgkg}^{-1}\right)$ and the USEPA screening level $(0.68 \mathrm{mgkg}-1)([21],[22])$.

The concentration of $\mathrm{Zn}$ ranged from $14.40 \mathrm{mg} / \mathrm{kg}$ - $169.53 \mathrm{mg} / \mathrm{kg}$ with Lagos mainland indicating the lowest and Apapa indicating the highest concentration. There were variance in $\mathrm{Zn}$ concentrations between local government areas. Surulere and Epe also have concentrations higher than $100 \mathrm{mg} / \mathrm{kg}$. The high concentration of $\mathrm{Zn}$ may be through wear and tear of automobile tyres and during traffic congestion, which is a main problem on Apapa road to Lagos seaport where trucks and containers are packed. The elevated $\mathrm{Zn}$ content may have originated due to wear and tear of vulcanized vehicle tires, and corrosion of galvanized automobile parts ([23], [24]; [25]). Dustiness on the other hand may be the reason for the high concentration of Zinc. There are a number of sources of zinc in the houses such as rubber, paints and fillers [26].

The concentration of $\mathrm{Pb}$ ranged from $66.47 \mathrm{mg} / \mathrm{kg}-129.87 \mathrm{mg} / \mathrm{kg}$. Surulere indicated the lowest concentration $(66.47 \mathrm{mg} / \mathrm{kg})$ while the highest was recorded in Mushin. This is not mainly from the use of leaded paints as always mentioned by most authors, the number of occupants in households might be a likely significant factor as reported also by [27]. Generally, Pb is high in all local government areas, as lead is a major pollutant in urban cities. Just like other cities, it is still a major pollutant as reported in Shah Alam city by [28]. Similar result was also reported by [29]. The age of the buildings in Mushin might also be a factor for high concentration as well as the presence of motor parks.

Copper and Chromium were found at lower concentrations than other heavy metals reported. The concentration of copper ranged from $8.27 \mathrm{mg} / \mathrm{kg}-162.27 \mathrm{mg} / \mathrm{kg}$ with the lowest concentration at Lagos Mainland local government and then highest at IfakoIjaiye local government area. Chromium being the metal with the lowest concentration ranged from $1.56 \mathrm{mg} / \mathrm{kg}-22.60 \mathrm{mg} / \mathrm{kg}$ with Alimosho local government as the lowest and Badagry having the highest, Activities of nearby industries might be responsible for the values reported [30]. The range of chromium concentration is within limits for residential levels and lead concentration for most of the sampling locations indicated that the concentration range for these locations are well above the $50^{\text {th }}$ percentile of the limit set by California Human Health Limits [31]. It was also the metal with the lowest concentration in then study carried out by [32] in Malaysia. 
International Journal of Advances in Scientific Research and Engineering (ijasre), Vol 6 (3), March -2020

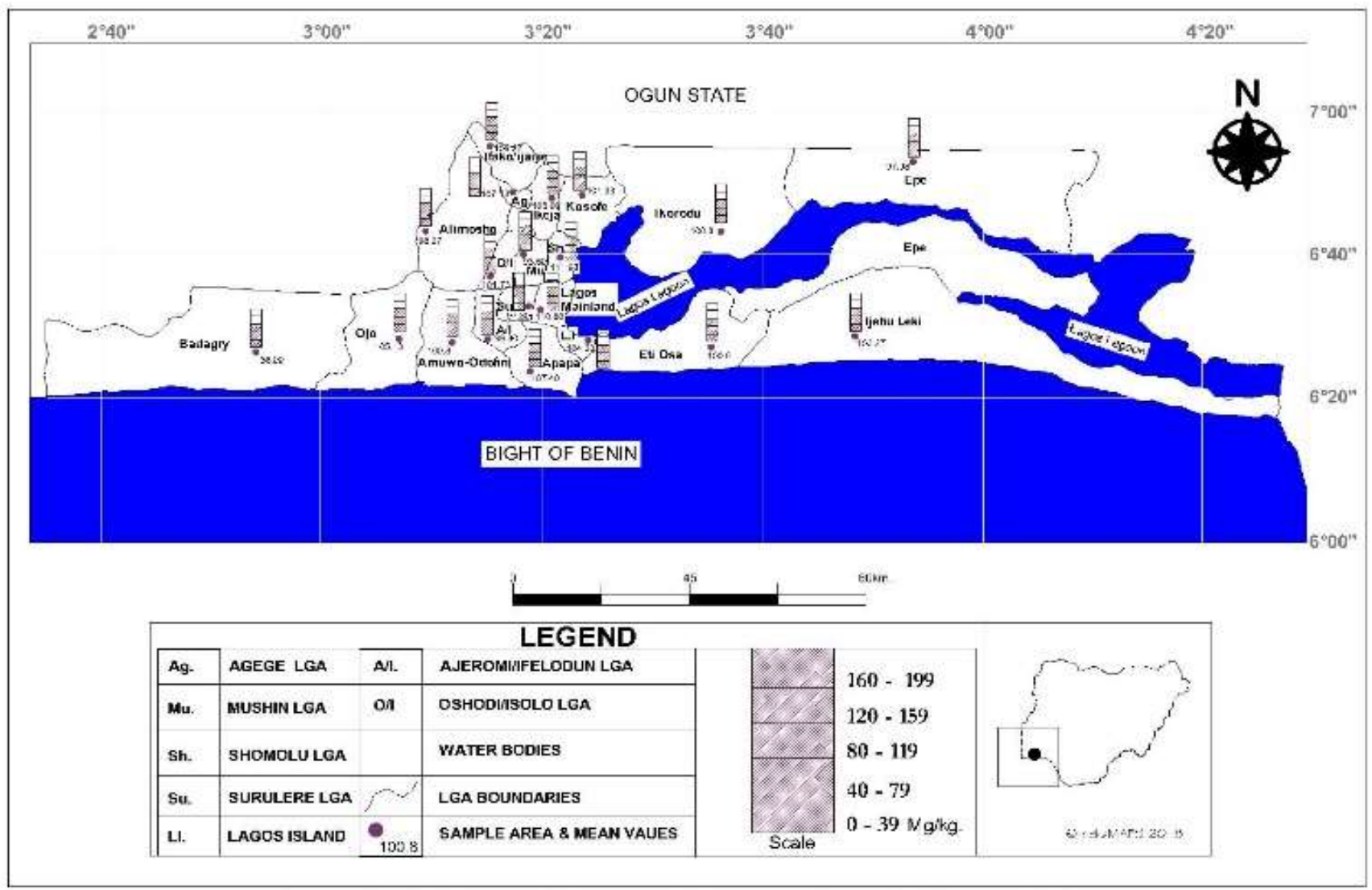

Lagos, showing Sampling Areas \& Recorded Values for Atseric (As.)

Figure 2.0: Map of Lagos State showing the metal concentration of Arsenic

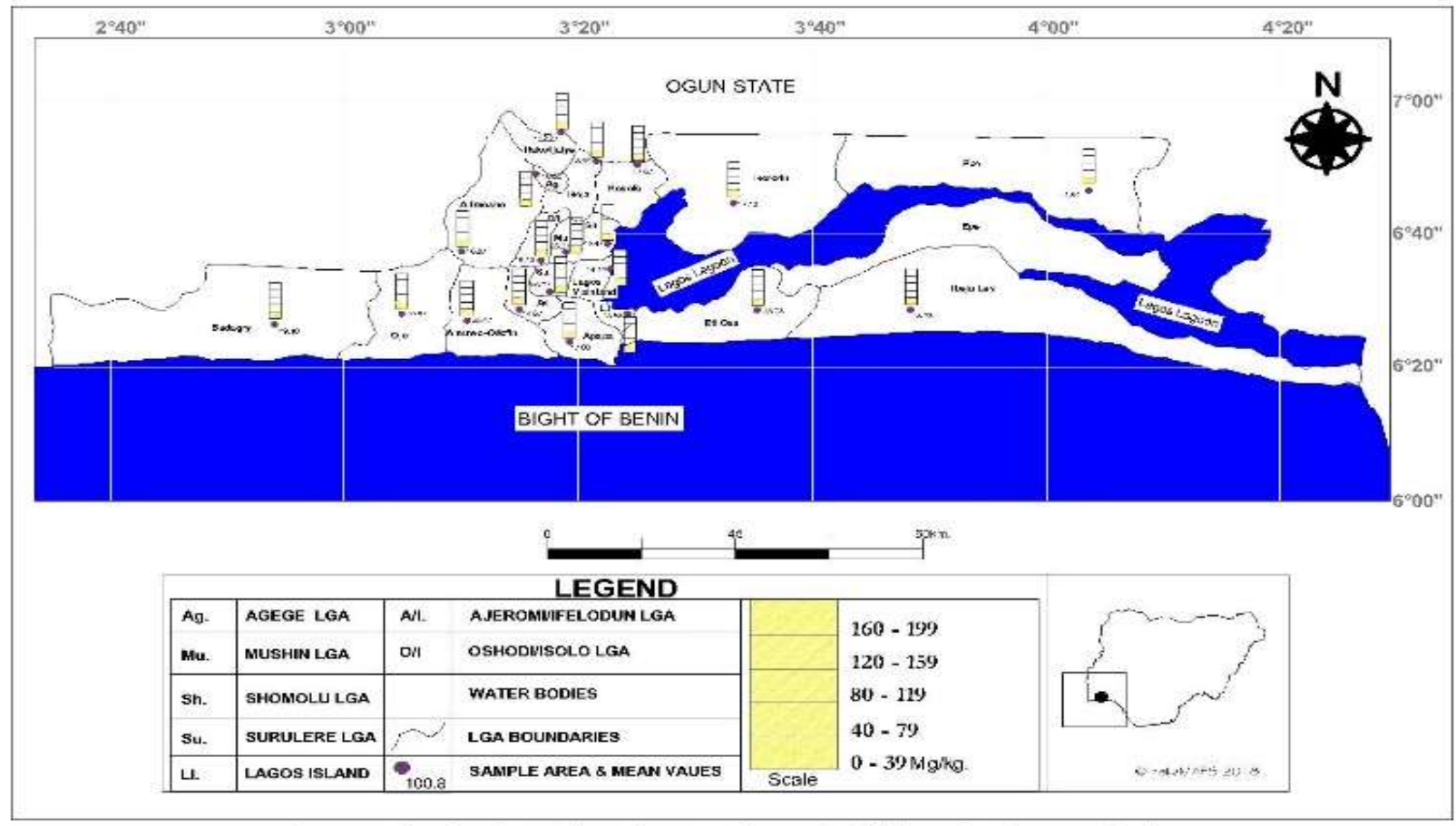

Lagos, showing Sampling Areas \& Recorded Values for Copper. (Cu.)

Figure 3.0: Map of Lagos State showing the metal concentration of Copper 
International Journal of Advances in Scientific Research and Engineering (ijasre), Vol 6 (3), March -2020

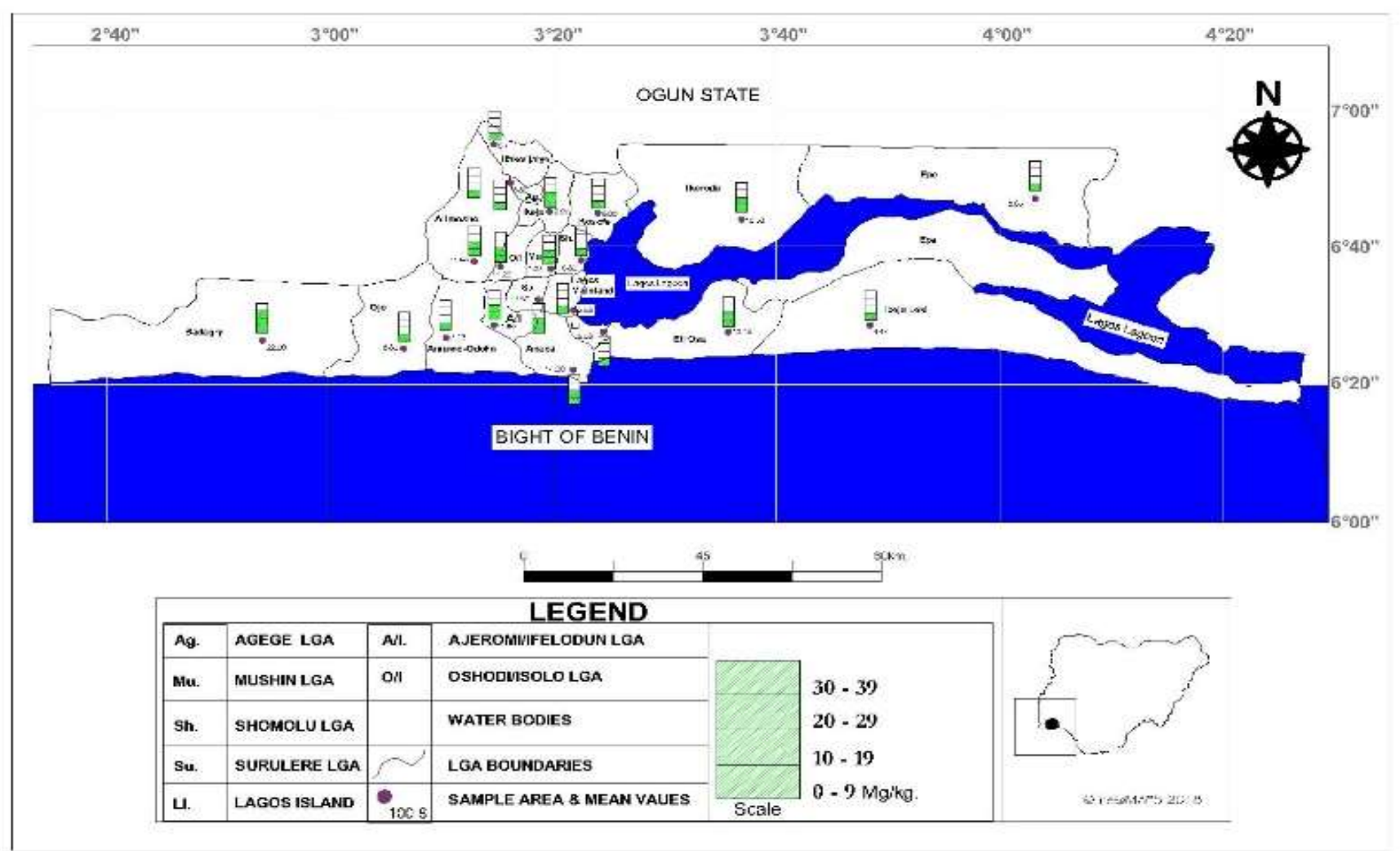

Lagos, showing Sampling Areas \& Recorded Values for Chromium. (Cr.)

Figure 4.0: Map of Lagos State showing the metal concentration of Chromium 


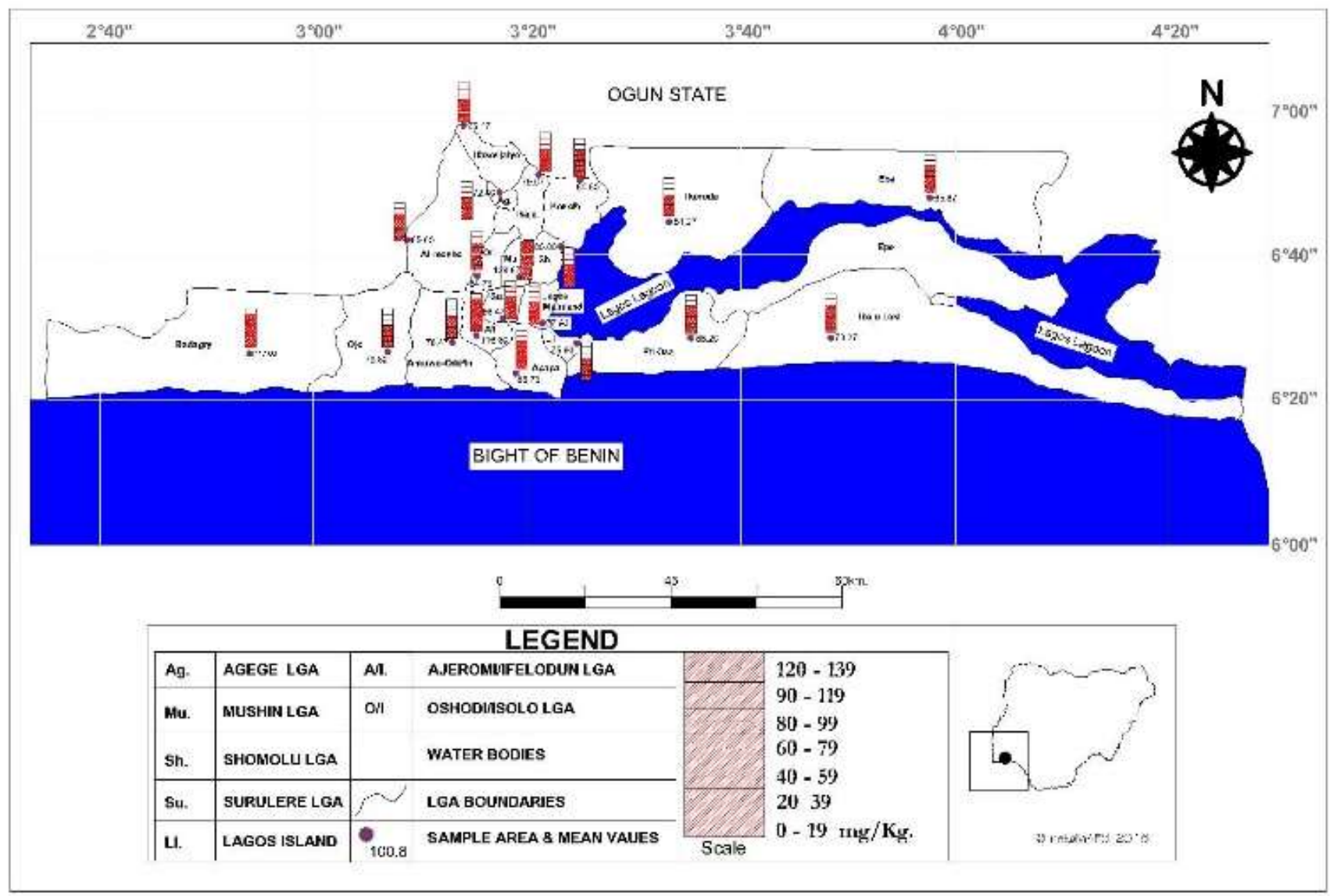

Lagos, showing Sampling Areas \& Recorded Values for Lead. (Pb.)

Figure 5.0 Map of Lagos State showing the metal concentration of Lead 


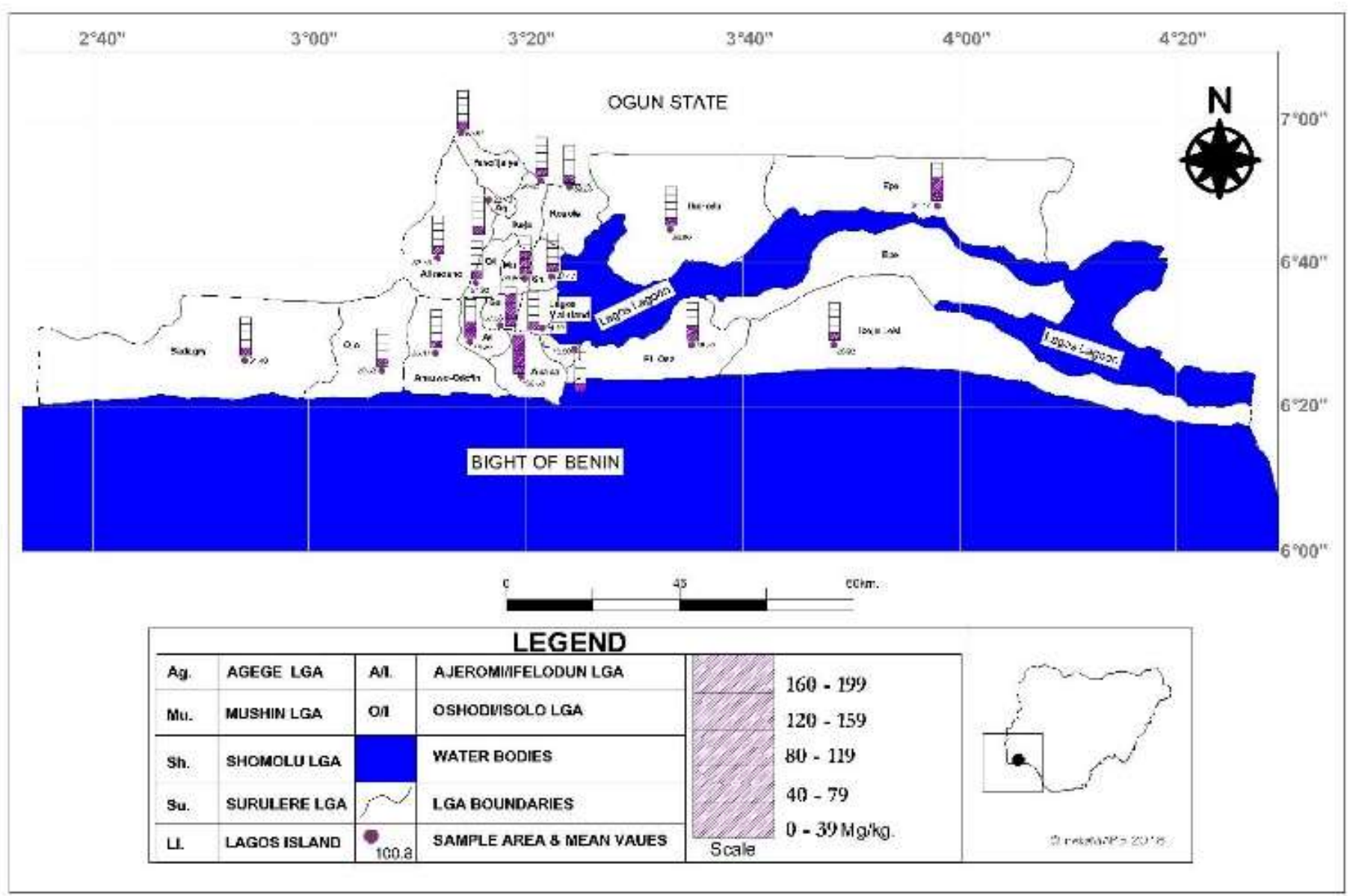

Lagos, showing Sampling Areas \& Recorded Values for Zinc. (Zn.)

Figure 6.0 Map of Lagos State showing the metal concentration of Zinc 
International Journal of Advances in Scientific Research and Engineering (ijasre), Vol 6 (3), March -2020

Table 4.0 Comparison of the heavy metals (in $\mathrm{mg} / \mathrm{kg}$ ) from this study to other studies

\begin{tabular}{|c|c|c|c|c|c|c|}
\hline \multirow[t]{2}{*}{ Sources and references } & \multirow[t]{2}{*}{ Sample Area } & \multicolumn{5}{|c|}{ Concentration (mg/kg) } \\
\hline & & $\mathbf{P b}$ & $\mathbf{Z n}$ & $\mathrm{Cr}$ & As & $\mathbf{C u}$ \\
\hline This study & Housing areas, Lagos, Nigeria & 85 & 54.04 & 9.23 & 102.89 & 25.37 \\
\hline Tong, (1998) & $\begin{array}{l}\text { Nursery school and Kindergarten, } \\
\text { Hong Kong }\end{array}$ & 199.96 & 2229.56 & - & - & - \\
\hline Rasmussen et al. (2001) & Housing areas, Ottawa, Canada & 405.56 & 716.90 & 86.70 & - & - \\
\hline Chattopadhyay et al. (2003) & Housing areas, Sydney, Australia & 85.2 & 437.0 & 64.3 & - & - \\
\hline Jaradat et al. (2004) & Industrial area, Jordan & 128 & 746 & 38 & - & - \\
\hline Turner, (2011) & Housing areas, United Kingdom & 181 & 666 & - & - & - \\
\hline Mohd et al. (2007) & Nursery in Dungun Town, china & 51 & 558 & - & - & - \\
\hline Wang et al. (2011) & Kindergarten, Kaifeng, China & 242.99 & 297.32 & 82.13 & - & - \\
\hline Habil and Taneja (2011) & School, Agra, India & 18.65 & 58.47 & 3.71 & & \\
\hline Mohd et al. (2013) & Preschool, Malaysia & 253.5 & 144.9 & 11.9 & & \\
\hline Saeed and Sayed (2017) & Household, Iran & 93.4 & - & 83.5 & - & 189 \\
\hline Dundar and Ozdemir (2005) & Housing areas & 121 & - & 104 & & 27 \\
\hline Amjad et al. (2016) & $\begin{array}{l}\text { Residential Houses, United } \\
\text { Kingdom }\end{array}$ & 13.2 & - & 9.89 & - & 25.0 \\
\hline Hao et al. (2014) & Nursey and Primary school in China & 180.9 & 461.5 & 149.2 & 13.2 & 70.8 \\
\hline Culbard and Johnson (1984) & Household, South west England & - & - & - & 1160 & - \\
\hline Rieuwerts et al. (2006) & Household, South west England & - & - & - & 486 & - \\
\hline Daniel et al. (2017) & Household, South west England & - & - & - & 104 & - \\
\hline
\end{tabular}

The concentration of heavy metals in this study is compared with previous investigated values from other cities in the world as shown in Table (4.1). The result however, showed that heavy metals studied here have an approximately lower concentration than reported from other previously studied cities. This may be attributed to the fact that most of the cities are more industrialized than Lagos as also mentioned by [30]. The metals with the highest concentration from this study was As and on the other hand, the concentration was found to be in a slightly close range with investigated data from household in Southwest England [20]. The low level of the concentration of Arsenic in this study compared to the value presented by [18] and [19], might be attributed to the fact that the previous studies study areas were two separated former mining village. These concentrations can therefore be considered high compared to a non-mining area in Lagos metropolis. The study presented Chromium to be the metal with the lowest concentration and 
International Journal of Advances in Scientific Research and Engineering (ijasre), Vol 6 (3), March -2020

obviously lower than all the values reported in the compared researches, only in a school, in Agra, India [20], which has a concentration three times lower than that reported in Lagos according to the study.

\subsection{Risk Assessment}

5.0 Daily Intake of Heavy Metals

\begin{tabular}{|c|c|c|c|c|c|c|c|c|c|}
\hline $\begin{array}{l}\text { Heavy } \\
\text { Metal }\end{array}$ & & $D_{\text {ing }}$ & & & $\mathbf{D}_{\text {inh }}$ & & & $\mathbf{D}_{\text {dermal }}$ & \\
\hline \multirow{4}{*}{$\mathbf{Z n}$} & Level & Children & Adult & Level & Children & Adult & Level & Children & Adult \\
\hline & Minimum & $7.16 \times 10^{-5}$ & $8.15 \times 10^{-6}$ & Minimum & $2.13 \times 10^{-9}$ & $1.20 \times 10^{-9}$ & Minimum & $2.13 \times 10^{-7}$ & $3.25 \times 10^{-7}$ \\
\hline & Maximum & $1.11 \times 10^{-3}$ & $1.19 \times 10^{-4}$ & Maximum & $2.89 \times 10^{-9}$ & $1.76 \times 10^{-8}$ & Maximum & $3.12 \times 10^{-6}$ & $4.77 \times 10^{-6}$ \\
\hline & Minimum & $3.26 \times 10^{-5}$ & $1.40 \times 10^{-5}$ & Minimum & $3.47 \times 10^{-10}$ & $2.05 \times 10^{-9}$ & Minimum & $2.73 \times 10^{-6}$ & $1.67 \times 10^{-5}$ \\
\hline \multirow[t]{2}{*}{ As } & Maximum & $6.31 \times 10^{-5}$ & $2.70 \times 10^{-5}$ & Maximum & $2.05 \times 10^{-9}$ & $3.98 \times 10^{-9}$ & Maximum & $5.30 \times 10^{-6}$ & $3.24 \times 10^{-5}$ \\
\hline & Minimum & $5.44 \times 10^{-5}$ & $5.83 \times 10^{-6}$ & Minimum & $1.52 \times 10^{-9}$ & $8.57 \times 10^{-10}$ & Minimum & $1.52 \times 10^{-7}$ & $2.32 \times 10^{-7}$ \\
\hline \multirow[t]{2}{*}{$\mathrm{Cu}$} & Maximum & $3.69 \times 10^{-4}$ & $1.14 \times 10^{-4}$ & Maximum & $2.98 \times 10^{-8}$ & $1.68 \times 10^{-8}$ & Maximum & $2.99 \times 10^{-6}$ & $4.56 \times 10^{-6}$ \\
\hline & Minimum & $1.24 \times 10^{-5}$ & $5.32 \times 10^{-6}$ & Minimum & $9.10 \times 10^{10}$ & $2.36 \times 10^{-9}$ & Minimum & $1.05 \times 10^{-7}$ & $2.12 \times 10^{-7}$ \\
\hline \multirow[t]{2}{*}{$\mathbf{P b}$} & Maximum & $7.32 \times 10^{-5}$ & $3.14 \times 10^{-5}$ & Maximum & $1.69 \times 10^{-9}$ & $4.61 \times 10^{-9}$ & Maximum & $3.47 \times 10^{-7}$ & $1.25 \times 10^{-6}$ \\
\hline & Minimum & $1.43 \times 10^{-6}$ & $6.11 \times 10^{-7}$ & Minimum & $3.98 \times 10^{-11}$ & $8.99 \times 10^{-11}$ & Minimum & $3.99 \times 10^{-9}$ & $2.44 \times 10^{-8}$ \\
\hline $\mathrm{Cr}$ & Maximum & $1.27 \times 10^{-5}$ & $5.46 \times 10^{-6}$ & Maximum & $3.56 \times 10^{-10}$ & $8.03 \times 10^{-10}$ & Maximum & $3.57 \times 10^{-8}$ & $2.18 \times 10^{-7}$ \\
\hline
\end{tabular}

For non-cancer risk in children, ingestion appears to be the main exposure route followed by dermal contact and exposure by inhalation. The same thing applies to adult as well and this is similar to other reports ( [7],[8]). The highest $\mathrm{D}_{\text {ing }}$ value was $1.11 \times 10^{-3}$ for Zinc and the lowest $\mathrm{D}_{\text {ing }}$ value was $1.27 \times 10^{-3}$. These findings can be attributed to the more vulnerability of children to the toxic substances [33]. Furthermore, children are also more sensitive to heavy metals in indoor dust due to their behavior such as hand-tomouth activities, crawling and fast growth rate [34]. [35] mentioned that indoor dust particles ingestion is the main exposure route of toxic metals by children as they like to play on the floor of the house and indirectly ingest it.

The exposure route by ingestion was significantly higher than Inhalation and dermal in the order ingestion >dermal>inhalation. However, daily intake of dust via Inhalation was higher in adult than children for all heavy metals studied except for copper. By dermal contact, children exposure to dust particles was higher than in adult for Zinc, lower than adult for Arsenic, lower than adult for copper, lower than adult for lead and lower than adult for chromium as well.

Across all metals of study, the metal with the lowest value via the three route of exposure (ingestion, inhalation and dermal) in adult and children was chromium and the highest was zinc in both children and adult.

\subsubsection{Heavy metals Non-Carcinogenic Risk Assessment.}

Table 6.0 Hazard Indexes and Quotients for Metals Exposure in Children and Adults

\begin{tabular}{lllllllllll}
\hline & Arsenic & & Zinc & & Copper & & Lead & \multicolumn{2}{c}{ Chromium } \\
& Children & Adult & Children & Adult & Children & Adult & Children & Adult & Children & Adult \\
& HI & HI & HI & HI & HI & HI & HI & HI & HI & HI \\
\hline 1 & $2.16 \times$ & $3.21 \times$ & $1.15 \times$ & $1.46 \times$ & $2.65 \times$ & $3.22 \times$ & $1.39 \times$ & $1.56 \times$ & $2.40 \times 10^{-3}$ & $2.71 \times$ \\
& $10^{-1}$ & $10^{-1}$ & $10^{-3}$ & $10^{-4}$ & $10^{-3}$ & $10^{-4}$ & $10^{-2}$ & $10^{-3}$ & & $10^{-3}$ \\
2 & $2.25 \times$ & $3.38 \times$ & $5.05 \times$ & $6.40 \times$ & $1.74 \times$ & $2.12 \times$ & $1.19 \times$ & $1.33 \times$ & $1.89 \times 10^{-3}$ & $2.13 \times$ \\
& $10^{-1}$ & $10^{-1}$ & $10^{-4}$ & $10^{-5}$ & $10^{-3}$ & $10^{-4}$ & $10^{-2}$ & $10^{-3}$ & & $10^{-3}$
\end{tabular}


International Journal of Advances in Scientific Research and Engineering (ijasre), Vol 6 (3), March -2020

\begin{tabular}{|c|c|c|c|c|c|c|c|c|c|c|}
\hline 3 & $\begin{array}{l}2.14 \mathrm{x} \\
10^{-1}\end{array}$ & $\begin{array}{l}3.26 \mathrm{x} \\
10^{-1}\end{array}$ & $\begin{array}{l}5.99 \times \\
10^{-4}\end{array}$ & $\begin{array}{l}7.59 x \\
10^{-5}\end{array}$ & $\begin{array}{l}2.29 \mathrm{x} \\
10^{-3}\end{array}$ & $\begin{array}{l}2.78 \mathrm{x} \\
10^{-4}\end{array}$ & $\begin{array}{l}1.30 \mathrm{x} \\
10^{-2}\end{array}$ & $\begin{array}{l}1.44 \mathrm{x} \\
10^{-3}\end{array}$ & $9.60 \times 10^{-4}$ & $\begin{array}{l}1.08 \mathrm{x} \\
10^{-3}\end{array}$ \\
\hline 4 & $\begin{array}{l}1.87 \mathrm{x} \\
10^{-1}\end{array}$ & $\begin{array}{l}2.71 \mathrm{x} \\
10^{-1}\end{array}$ & $\begin{array}{l}6.98 \times \\
10^{-4}\end{array}$ & $\begin{array}{l}8.85 x \\
10^{-5}\end{array}$ & $\begin{array}{l}3.19 \mathrm{x} \\
10^{-3}\end{array}$ & $\begin{array}{l}3.87 \mathrm{x} \\
10^{-4}\end{array}$ & $\begin{array}{l}1.91 \mathrm{x} \\
10^{-2}\end{array}$ & $\begin{array}{l}2.15 \mathrm{x} \\
10^{-3}\end{array}$ & $4.85 \times 10^{-3}$ & $\begin{array}{l}5.48 \times \\
10^{-3}\end{array}$ \\
\hline 5 & $\begin{array}{l}2.36 \mathrm{x} \\
10^{-1}\end{array}$ & $\begin{array}{l}3.53 \mathrm{x} \\
10^{-1}\end{array}$ & $\begin{array}{l}6.11 \times \\
10^{-4}\end{array}$ & $\begin{array}{l}7.74 \mathrm{x} \\
10^{-5}\end{array}$ & $\begin{array}{l}3.20 \mathrm{x} \\
10^{-3}\end{array}$ & $\begin{array}{l}3.89 \mathrm{x} \\
10^{-4}\end{array}$ & $\begin{array}{l}1.31 \mathrm{x} \\
10^{-2}\end{array}$ & $\begin{array}{l}1.47 \mathrm{x} \\
10^{-3}\end{array}$ & $1.46 \times 10^{-3}$ & $\begin{array}{l}1.65 \mathrm{x} \\
10^{-3}\end{array}$ \\
\hline 6 & $\begin{array}{l}2.30 \mathrm{x} \\
10^{-1}\end{array}$ & $\begin{array}{l}3.50 \mathrm{x} \\
10^{-1}\end{array}$ & $\begin{array}{l}3.20 \mathrm{x} \\
10^{-4}\end{array}$ & $\begin{array}{l}4.06 \mathrm{x} \\
10^{-5}\end{array}$ & $\begin{array}{l}1.36 \mathrm{x} \\
10^{-3}\end{array}$ & $\begin{array}{l}1.65 \mathrm{x} \\
10^{-4}\end{array}$ & $\begin{array}{l}1.29 \mathrm{x} \\
10^{-2}\end{array}$ & $\begin{array}{l}1.43 \mathrm{x} \\
10^{-3}\end{array}$ & $5.43 \times 10^{-4}$ & $\begin{array}{l}6.13 \times \\
10^{-4}\end{array}$ \\
\hline 7 & $\begin{array}{l}2.00 \mathrm{x} \\
10^{-1}\end{array}$ & $\begin{array}{l}2.95 \mathrm{x} \\
10^{-1}\end{array}$ & $\begin{array}{l}2.08 \mathrm{x} \\
10^{-3}\end{array}$ & $\begin{array}{l}2.64 \mathrm{x} \\
10^{-4}\end{array}$ & $\begin{array}{l}3.79 \mathrm{x} \\
10^{-3}\end{array}$ & $\begin{array}{l}4.60 \mathrm{x} \\
10^{-4}\end{array}$ & $\begin{array}{l}2.12 \mathrm{x} \\
10^{-2}\end{array}$ & $\begin{array}{l}2.38 \mathrm{x} \\
10^{-3}\end{array}$ & $2.38 \times 10^{-3}$ & $\begin{array}{l}2.68 x \\
10^{-3}\end{array}$ \\
\hline 8 & $\begin{array}{l}2.26 \mathrm{x} \\
10^{-1}\end{array}$ & $\begin{array}{l}3.39 \mathrm{x} \\
10^{-1}\end{array}$ & $\begin{array}{l}3.77 \times \\
10^{-3}\end{array}$ & $\begin{array}{l}4.78 \times \\
10^{-4}\end{array}$ & $\begin{array}{l}2.79 \mathrm{x} \\
10^{-3}\end{array}$ & $\begin{array}{l}3.39 \mathrm{x} \\
10^{-4}\end{array}$ & $\begin{array}{l}1.40 \mathrm{x} \\
10^{-2}\end{array}$ & $\begin{array}{l}1.57 \mathrm{x} \\
10^{-3}\end{array}$ & $3.01 \times 10^{-3}$ & $\begin{array}{l}3.39 \mathrm{x} \\
10^{-3}\end{array}$ \\
\hline 9 & $\begin{array}{l}2.24 \mathrm{x} \\
10^{-1}\end{array}$ & $\begin{array}{l}3.35 \mathrm{x} \\
10^{-1}\end{array}$ & $\begin{array}{l}6.64 \mathrm{x} \\
10^{-4}\end{array}$ & $\begin{array}{l}8.41 \mathrm{x} \\
10^{-5}\end{array}$ & $\begin{array}{l}2.67 \times \\
10^{-2}\end{array}$ & $\begin{array}{l}3.24 \mathrm{x} \\
10^{-3}\end{array}$ & $\begin{array}{l}1.24 \mathrm{x} \\
10^{-2}\end{array}$ & $\begin{array}{l}1.39 \mathrm{x} \\
10^{-3}\end{array}$ & $1.39 \times 10^{-3}$ & $\begin{array}{l}1.57 \mathrm{x} \\
10^{-3}\end{array}$ \\
\hline 10 & $\begin{array}{l}2.23 \mathrm{x} \\
10^{-1}\end{array}$ & $\begin{array}{l}3.35 \mathrm{x} \\
10^{-1}\end{array}$ & $\begin{array}{l}8.13 \mathrm{x} \\
10^{-4}\end{array}$ & $\begin{array}{l}1.03 \mathrm{x} \\
10^{-4}\end{array}$ & $\begin{array}{l}2.82 \mathrm{x} \\
10^{-3}\end{array}$ & $\begin{array}{l}3.42 \mathrm{x} \\
10^{-4}\end{array}$ & $\begin{array}{l}1.33 \mathrm{x} \\
10^{-2}\end{array}$ & $\begin{array}{l}1.49 \mathrm{x} \\
10^{-3}\end{array}$ & $2.26 \times 10^{-3}$ & $\begin{array}{l}2.55 x \\
10^{-3}\end{array}$ \\
\hline 11 & $\begin{array}{l}2.20 \mathrm{x} \\
10^{-1}\end{array}$ & $\begin{array}{l}3.29 \mathrm{x} \\
10^{-1}\end{array}$ & $\begin{array}{l}5.66 \mathrm{x} \\
10^{-4}\end{array}$ & $\begin{array}{l}7.18 \mathrm{x} \\
10^{-5}\end{array}$ & $\begin{array}{l}1.85 \mathrm{x} \\
10^{-3}\end{array}$ & $\begin{array}{l}2.25 \mathrm{x} \\
10^{-4}\end{array}$ & $\begin{array}{l}1.29 \mathrm{x} \\
10^{-2}\end{array}$ & $\begin{array}{l}1.44 \mathrm{x} \\
10^{-3}\end{array}$ & $1.53 \times 10^{-3}$ & $\begin{array}{l}1.73 \mathrm{x} \\
10^{-3}\end{array}$ \\
\hline 12 & $\begin{array}{l}2.24 \mathrm{x} \\
10^{-1}\end{array}$ & $\begin{array}{l}3.35 \times \\
10^{-1}\end{array}$ & $\begin{array}{l}3.10 \mathrm{x} \\
10^{-3}\end{array}$ & $\begin{array}{l}3.92 \times \\
10^{-4}\end{array}$ & $\begin{array}{l}2.44 \mathrm{x} \\
10^{-3}\end{array}$ & $\begin{array}{l}2.97 \mathrm{x} \\
10^{-4}\end{array}$ & $\begin{array}{l}1.38 \times \\
10^{-2}\end{array}$ & $\begin{array}{l}1.55 \times \\
10^{-3}\end{array}$ & $3.58 \times 10^{-3}$ & $\begin{array}{l}4.04 \times \\
10^{-3}\end{array}$ \\
\hline 13 & $\begin{array}{l}2.21 \mathrm{x} \\
10^{-1}\end{array}$ & $\begin{array}{l}3.31 \mathrm{x} \\
10^{-1}\end{array}$ & $\begin{array}{l}4.58 \times \\
10^{-4}\end{array}$ & $\begin{array}{l}5.80 \times \\
10^{-5}\end{array}$ & $\begin{array}{l}3.06 \mathrm{x} \\
10^{-3}\end{array}$ & $\begin{array}{l}3.71 \times \\
10^{-4}\end{array}$ & $\begin{array}{l}1.30 \mathrm{x} \\
10^{-2}\end{array}$ & $\begin{array}{l}1.45 \mathrm{x} \\
10^{-3}\end{array}$ & $1.95 \times 10^{-3}$ & $\begin{array}{l}2.20 \mathrm{x} \\
10^{-3}\end{array}$ \\
\hline 14 & $\begin{array}{l}2.11 \mathrm{x} \\
10^{-1}\end{array}$ & $\begin{array}{l}3.32 \times \\
10^{-1}\end{array}$ & $\begin{array}{l}4.56 \mathrm{x} \\
10^{-4}\end{array}$ & $\begin{array}{l}5.78 \times \\
10^{-5}\end{array}$ & $\begin{array}{l}1.75 \mathrm{x} \\
10^{-3}\end{array}$ & $\begin{array}{l}2.13 \mathrm{x} \\
10^{-4}\end{array}$ & $\begin{array}{l}1.19 \mathrm{x} \\
10^{-2}\end{array}$ & $\begin{array}{l}1.35 \mathrm{x} \\
10^{-3}\end{array}$ & $1.89 \times 10^{-3}$ & $\begin{array}{l}2.13 \mathrm{x} \\
10^{-3}\end{array}$ \\
\hline 15 & $\begin{array}{l}1.32 \mathrm{x} \\
10^{-1}\end{array}$ & $\begin{array}{l}1.82 \mathrm{x} \\
10^{-1}\end{array}$ & $\begin{array}{l}2.57 \times \\
10^{-4}\end{array}$ & $\begin{array}{l}3.26 \mathrm{x} \\
10^{-5}\end{array}$ & $\begin{array}{l}3.30 \mathrm{x} \\
10^{-3}\end{array}$ & $\begin{array}{l}4.01 \mathrm{x} \\
10^{-4}\end{array}$ & $\begin{array}{l}3.77 \mathrm{x} \\
10^{-3}\end{array}$ & $\begin{array}{l}4.04 \mathrm{x} \\
10^{-4}\end{array}$ & $2.18 \times 10^{-3}$ & $\begin{array}{l}2.46 \times \\
10^{-3}\end{array}$ \\
\hline 16 & $\begin{array}{l}2.19 \mathrm{x} \\
10^{-1}\end{array}$ & $\begin{array}{l}3.29 \mathrm{x} \\
10^{-1}\end{array}$ & $\begin{array}{l}3.69 x \\
10^{-4}\end{array}$ & $\begin{array}{l}4.68 \mathrm{x} \\
10^{-5}\end{array}$ & $\begin{array}{l}2.55 \mathrm{x} \\
10^{-3}\end{array}$ & $\begin{array}{l}3.10 \mathrm{x} \\
10^{-4}\end{array}$ & $\begin{array}{l}1.25 \mathrm{x} \\
10^{-2}\end{array}$ & $\begin{array}{l}1.39 \mathrm{x} \\
10^{-3}\end{array}$ & $1.19 \times 10^{-3}$ & $\begin{array}{l}1.34 \mathrm{x} \\
10^{-3}\end{array}$ \\
\hline 17 & $\begin{array}{l}2.13 \mathrm{x} \\
10^{-1}\end{array}$ & $\begin{array}{l}3.20 \mathrm{x} \\
10^{-1}\end{array}$ & $\begin{array}{l}8.87 \times \\
10^{-4}\end{array}$ & $\begin{array}{l}1.12 \mathrm{x} \\
10^{-4}\end{array}$ & $\begin{array}{l}2.91 \mathrm{x} \\
10^{-3}\end{array}$ & $\begin{array}{l}3.53 \mathrm{x} \\
10^{-4}\end{array}$ & $\begin{array}{l}1.40 \mathrm{x} \\
10^{-2}\end{array}$ & $\begin{array}{l}1.55 \mathrm{x} \\
10^{-3}\end{array}$ & $1.72 \times 10^{-3}$ & $\begin{array}{l}1.94 \mathrm{x} \\
10^{-3}\end{array}$ \\
\hline 18 & $\begin{array}{l}2.10 \mathrm{x} \\
10^{-1}\end{array}$ & $\begin{array}{l}3.15 \mathrm{x} \\
10^{-1}\end{array}$ & $\begin{array}{l}1.65 \mathrm{x} \\
10^{-3}\end{array}$ & $\begin{array}{l}2.09 \mathrm{x} \\
10^{-4}\end{array}$ & $\begin{array}{l}2.41 \mathrm{x} \\
10^{-3}\end{array}$ & $\begin{array}{l}2.93 \mathrm{x} \\
10^{-4}\end{array}$ & $\begin{array}{l}1.90 \mathrm{x} \\
10^{-2}\end{array}$ & $\begin{array}{l}2.14 \mathrm{x} \\
10^{-3}\end{array}$ & $2.53 \times 10^{-3}$ & $\begin{array}{l}2.86 \times \\
10^{-3}\end{array}$ \\
\hline 19 & $\begin{array}{l}2.06 \mathrm{x} \\
10^{-1}\end{array}$ & $\begin{array}{l}3.09 \mathrm{x} \\
10^{-1}\end{array}$ & $\begin{array}{l}3.50 x \\
10^{-3}\end{array}$ & $\begin{array}{l}4.44 x \\
10^{-4}\end{array}$ & $\begin{array}{l}9.22 \mathrm{x} \\
10^{-3}\end{array}$ & $\begin{array}{l}1.12 \mathrm{x} \\
10^{-3}\end{array}$ & $\begin{array}{l}1.10 \mathrm{x} \\
10^{-2}\end{array}$ & $\begin{array}{l}1.22 \mathrm{x} \\
10^{-3}\end{array}$ & $3.75 \times 10^{-3}$ & $\begin{array}{l}4.23 x \\
10^{-3}\end{array}$ \\
\hline 20 & $\begin{array}{l}1.85 \mathrm{x} \\
10^{-1}\end{array}$ & $\begin{array}{l}3.10 \mathrm{x} \\
10^{-1}\end{array}$ & $\begin{array}{l}7.50 \times \\
10^{-4}\end{array}$ & $\begin{array}{l}9.50 \mathrm{x} \\
10^{-5}\end{array}$ & $\begin{array}{l}2.77 \times \\
10^{-3}\end{array}$ & $\begin{array}{l}3.37 \mathrm{x} \\
10^{-4}\end{array}$ & $\begin{array}{l}1.14 \mathrm{x} \\
10^{-2}\end{array}$ & $\begin{array}{l}1.57 \mathrm{x} \\
10^{-3}\end{array}$ & $2.49 \times 10^{-3}$ & $\begin{array}{l}2.81 \mathrm{x} \\
10^{-3}\end{array}$ \\
\hline
\end{tabular}

Hazard Quotients for arsenic in children followed the order $\mathrm{HQ}_{\text {ing }}>\mathrm{HQ}_{\text {dermal }}>\mathrm{HQ}_{\text {inh }}$ and $\mathrm{HQ}$ for arsenic in adult followed the order $\mathrm{HQ}_{\text {dermal }}>\mathrm{HQ}_{\text {ing }}>\mathrm{HQ}_{\text {inh }}$. The Hazard Quotient for zinc in children followed the order $\mathrm{HQ}_{\text {inj }}>\mathrm{HQ}_{\text {dermal }}>\mathrm{HQ}_{\text {inh }}$ and $\mathrm{HQ}$ for adult in zinc had the $\mathrm{HQ}_{\text {inj }}$ and $\mathrm{HQ}_{\text {dermal }}$ slightly the same but greater than $\mathrm{HQ}_{\text {inh. }}$. The Hazard Quotient for copper in Children and adult followed the same order and was $\mathrm{HQ}_{\text {inj }}>\mathrm{HQ}_{\text {dermal }}>\mathrm{HQ}_{\text {inh }}$ and the $\mathrm{HQ}$ for copper in adult was in the order. The same was also found in Lead for both children and adult. The Hazard Quotient for chromium in children followed the order $\mathrm{HQ}_{\text {inj }}>\mathrm{HQ}_{\text {dermal }}>\mathrm{HQ}_{\text {inh }}$ and the $\mathrm{HQ}$ for chromium in adult followed the order $\mathrm{HQd}_{\text {ermal }}>\mathrm{HQ}_{\text {inj }}>\mathrm{HQ}_{\text {inh }}$.

The Hazard Index (HI) in adults was a bit higher than children in arsenic. In zinc and copper, the HI was higher in children than in adult; the same thing appears in lead and similar HI was recorded in chromium as well.

According to [10], indoor dust post adverse non-carcinogenic effect if its value is above 1, and from the study, none of the metals showed a HI value higher than 1 . This indicates that the indoor dust samples collected from the 20 local government areas in Lagos state pose no adverse non-carcinogenic health effect to the children and adults of the population. Similar values have been reported for indoor dust in precious researches ([33], [6] and [35]). 
International Journal of Advances in Scientific Research and Engineering (ijasre), Vol 6 (3), March -2020

\subsubsection{Carcinogenic Risk Assessment}

Table 7.0 Lifetime Cancer Risk and Total Lifetime Cancer Risk Values for Chromium

\begin{tabular}{|c|c|c|c|c|c|c|}
\hline \multicolumn{3}{|c|}{ Arsenic } & \multicolumn{2}{|l|}{ Lead } & \multicolumn{2}{|l|}{ Chromium } \\
\hline & Children & Adult & Children & Adult & Children & Adult \\
\hline & TLCR & TLCR & TLCR & TLCR & TLCR & TLCR \\
\hline 1 & $9.32 \times 10^{-5}$ & $8.10 \times 10^{-5}$ & $3.48 \times 10^{-7}$ & $1.81 \times 10^{-7}$ & $1.90 \times 10^{-8}$ & $8.44 \times 10^{-9}$ \\
\hline 2 & $9.82 \times 10^{-5}$ & $8.53 \times 10^{-5}$ & $3.76 \times 10^{-7}$ & $1.55 \times 10^{-7}$ & $1.49 \times 10^{-8}$ & $6.63 \times 10^{-9}$ \\
\hline 3 & $9.46 \times 10^{-5}$ & $8.22 \times 10^{-5}$ & $5.62 \times 10^{-7}$ & $1.67 \times 10^{-7}$ & $7.58 \times 10^{-9}$ & $3.37 \times 10^{-9}$ \\
\hline 4 & $7.88 \times 10^{-5}$ & $6.85 \times 10^{-5}$ & $3.85 \times 10^{-7}$ & $2.50 \times 10^{-7}$ & $3.83 \times 10^{-8}$ & $1.70 \times 10^{-8}$ \\
\hline 5 & $1.03 \times 10^{-4}$ & $8.91 \times 10^{-5}$ & $3.74 \times 10^{-7}$ & $1.71 \times 10^{-7}$ & $1.15 \times 10^{-8}$ & $5.12 \times 10^{-9}$ \\
\hline 6 & $1.02 \times 10^{-4}$ & $8.82 \times 10^{-5}$ & $6.23 \times 10^{-7}$ & $1.66 \times 10^{-7}$ & $4.29 \times 10^{-9}$ & $1.91 \times 10^{-9}$ \\
\hline 7 & $8.58 \times 10^{-5}$ & $7.45 \times 10^{-5}$ & $4.12 \times 10^{-7}$ & $2.77 \times 10^{-7}$ & $1.88 \times 10^{-8}$ & $8.34 \times 10^{-9}$ \\
\hline 8 & $9.84 \times 10^{-5}$ & $8.55 \times 10^{-5}$ & $3.63 \times 10^{-7}$ & $1.83 \times 10^{-7}$ & $2.37 \times 10^{-8}$ & $1.06 \times 10^{-8}$ \\
\hline 9 & $9.74 \times 10^{-5}$ & $8.46 \times 10^{-5}$ & $3.90 \times 10^{-7}$ & $1.61 \times 10^{-7}$ & $1.10 \times 10^{-8}$ & $4.88 \times 10^{-9}$ \\
\hline 10 & $9.74 \times 10^{-5}$ & $8.46 \times 10^{-5}$ & $3.77 \times 10^{-7}$ & $1.74 \times 10^{-7}$ & $1.79 \times 10^{-8}$ & $7.94 \times 10^{-9}$ \\
\hline 11 & $9.56 \times 10^{-5}$ & $8.30 \times 10^{-5}$ & $4.05 \times 10^{-7}$ & $1.68 \times 10^{-7}$ & $1.21 \times 10^{-8}$ & $5.37 \times 10^{-9}$ \\
\hline 12 & $9.74 \times 10^{-5}$ & $8.46 \times 10^{-5}$ & $3.80 \times 10^{-7}$ & $1.80 \times 10^{-7}$ & $2.83 \times 10^{-8}$ & $1.26 \times 10^{-8}$ \\
\hline 13 & $9.62 \times 10^{-5}$ & $8.36 \times 10^{-5}$ & $3.54 \times 10^{-7}$ & $1.69 \times 10^{-7}$ & $1.54 \times 10^{-8}$ & $6.84 \times 10^{-9}$ \\
\hline 14 & $9.63 \times 10^{-5}$ & $8.37 \times 10^{-5}$ & $1.06 \times 10^{-7}$ & $1.57 \times 10^{-7}$ & $1.49 \times 10^{-8}$ & $6.63 \times 10^{-9}$ \\
\hline 15 & $5.29 \times 10^{-5}$ & $4.60 \times 10^{-5}$ & $3.64 \times 10^{-7}$ & $4.70 \times 10^{-8}$ & $1.72 \times 10^{-8}$ & $7.63 \times 10^{-9}$ \\
\hline 16 & $9.56 \times 10^{-5}$ & $8.31 \times 10^{-5}$ & $4.06 \times 10^{-7}$ & $1.62 \times 10^{-7}$ & $9.38 \times 10^{-9}$ & $4.17 \times 10^{-9}$ \\
\hline 17 & $9.29 \times 10^{-5}$ & $8.07 \times 10^{-5}$ & $5.60 \times 10^{-7}$ & $1.81 \times 10^{-7}$ & $1.36 \times 10^{-8}$ & $6.03 \times 10^{-9}$ \\
\hline 18 & $9.15 \times 10^{-5}$ & $7.94 \times 10^{-5}$ & $3.20 \times 10^{-7}$ & $2.49 \times 10^{-7}$ & $2.00 \times 10^{-8}$ & $8.89 \times 10^{-9}$ \\
\hline 19 & $8.96 \times 10^{-5}$ & $7.79 \times 10^{-5}$ & $3.39 \times 10^{-7}$ & $1.42 \times 10^{-7}$ & $2.96 \times 10^{-8}$ & $1.32 \times 10^{-8}$ \\
\hline 20 & $9.01 \times 10^{-5}$ & $7.82 \times 10^{-5}$ & $1.16 \times 10^{-9}$ & $1.83 \times 10^{-7}$ & $1.97 \times 10^{-8}$ & $8.74 \times 10^{-9}$ \\
\hline
\end{tabular}

The highest TLCR value for Arsenic in children was $1.03 \times 10^{-4}$ and the lowest TLCR for Arsenic in children was $5.29 \times 10^{-5}$ while the highest TLCR for Arsenic in adults was $8.9 \times 10^{-5}$ and the lowest TLCR for Arsenic in adult was $4.60 \times 10^{-5}$.

The highest TLCR for lead in children was $6.23 \times 10^{-7}$ and the lowest TLCR for lead in children was $1.16 \times 10^{-9}$ while the highest TLCR for lead in adult was $2.77 \times 10^{-7}$ and the lowest TLCR for lead in adult was $4.70 \times 10^{-8}$.

The Lifetime Carcinogenic Risk in children across all heavy metals studied ranged from $\mathrm{LCR}_{\text {inj }}>\mathrm{LCR}_{\text {dermal }}>\mathrm{LCR}_{\text {inh. }}$. In adult, the same thing applies to lead and chromium, except for arsenic which had $\mathrm{LCR}_{\text {inj }}$ similar to $\mathrm{LCR}_{\text {dermal }}$ but both higher than $\mathrm{LCR}_{\text {inh. }}$.

The TLCR for adults and children were below the limit $\left(1 \times 10^{-6}-1 \times 10^{-4}\right)$ given by USEPA (2001) except in children which was slightly higher than the permissible limit in two local government areas; (Shomolu L.G.A 1.03 $\times 10^{-4}$ ) and (Lagos Mainland $1.02 \times 10^{-4}$ ). This indicates that the risk of carcinogenic effect occurring is likely in children with exposure to arsenic. [6] also reported a TLCR value $\left(4.01 \times 10^{-9}\right)$ and $\left(4.97 \times 10^{-9}\right)$ higher than the permissible limit for Arsenic in Children in nursery and primary school respectively in China.

\section{CONCLUSION}

This study presents a report of selected heavy metals $(\mathrm{As}, \mathrm{Pb}, \mathrm{Zn}, \mathrm{Cu}$ and $\mathrm{Cr}$ ) which are found in indoor dust samples collected in the 20 local government areas in Lagos State. The average concentration of the heavy metals reported were dominated in Arsenic followed by Zinc, Lead, Copper and Chromium. Arsenic showed the highest concentration. The whole local government is highly concentrated in Arsenic. However, Lagos is an industrial suburb, the uniqueness from this research is the high level of Arsenic. Lead is concentrated more in Mushin and Badagry. Zinc is very concentrated in Apapa, Surulere, Epe, Mushin and Agbado Ijaiye. Surulere is the most concentrated in Copper. 


\section{International Journal of Advances in Scientific Research and Engineering (ijasre), Vol 6 (3), March -2020}

Non-carcinogenic value was lower than 1 which is the permissible limit. This however indicated that the indoor dust samples collected from the 20 local government areas in Lagos state pose no adverse non-carcinogenic health effect to the children and adults. Carcinogenic risk assessment showed that only arsenic of all studied metals had a TLCR value lower than the permissible range of $1 \mathrm{x}$ $10^{-6}-1 \times 10^{-4}$ in two Local governments (Shomolu and Lagos Mainland). Therefore, exposure to arsenic might likely cause carcinogenic risk.

\section{ACKNOWLEGDMENT}

The Authors would like to thank the owner of the homes for giving the opportunity and cooperation to successfully perform thus study

\section{REFERENCES}

[1] Adekola, F.A. and Dosumu, O.O. (2001). Heavy metal determination in household dust from Ilorin City, Nigeria. Journal of Nigeria Society of Environment Biology.,3(1).

[2] Paustenbach, D.J., Finley, B.L. and Long, T.F. (1997). The critical role of house dust in understanding the hazards posed by contaminated soils. International Journal of Toxicology, 16, 339-362.

[3] Dundar, M.S. and Atundag, H. (2005). Heavy metal determination of house dust in Adapazari, Turkey, after earthquake. Trace Elements and Electrolytes 19, 55-58.

[4] Lu, X., Li, L.Y.,Wang, L., Lei, K., Huang, J. and Zhai, Y. (2009a). Contamination assessment of mercury and arsenic in roadway dust from Baoji, China. Atmospheric Environment ,43, 2489-2496.

[5] Morawska, L. and Salthammer, J. (2003). Indoor Environments: Airborne Particles and Settled Dust. Wiley-VCH, Weinheim.

[6] Hao C., Xinwei, L. and Loretta Y. (2014). Spatial distribution and risk assessment of metals in dust based on samples from nursery and primary schools of Xian, China. School of tourism and environment, Shaanxi Normal University Xian 710062, PR China. Journal of Atmospheric Environment , 88, 172-182.

[7] United States Environmental Protection Agency. (USEPA) (1996). Soil Screening Guidance: Technical Background Document. EPA/540/ R-95/128. Office of Solid Waste and Emergency Response.

[8] Ferreira-Baptista, L. and De Miguel, E., (2005). Geochemistry and risk assessment of street dust in Luanda, Angola: a tropical urban environment. Atmospheric Environment, 38, 4501-4512.

[9] Zheng, N., Liu, J., Wang, Q. and Liang, Z. (2010b). Heavy metals exposure of children from stairway and sidewalk dust in the smelting district, northeast of China. Atmospheric Environment, 44, 3239-3245.

[10] United States Environmental Protection Agency. (USEPA) (1989). Risk Assessment Guidance for Superfund. EPA/540/1e89/002. In: Human Health Evaluation Manual, vol. I. Office of Solid Waste and Emergency Response.

[11] United States Environmental Protection Agency. (USEPA) (2001). Supplemental Guidance for Developing Soil Screening Levels for Superfund Sites. OSWER 9355.4e24. Office of Solid Waste and Emergency Response.

[12] Van den Berg, R. (1995). Human Exposure to Soil Contamination: A Qualitative and Quantitative Analysis Towards Proposals for Human Toxicological Intervention Values. RIVM Report no. 725201011. National Institute of Public Health and Environmental Protection (RIVM), Bilthoven, the Netherlands.

[13] Zheng, N., Liu, J., Wang, Q. and Liang Z. (2010a). Health risk assessment of heavy metal exposure to street dust in the zinc smelting district, Northeast of China. Science of the Total Environment,408(4),726-733. 


\section{International Journal of Advances in Scientific Research and Engineering (ijasre), Vol 6 (3), March -2020}

[14] United States Environmental Protection Agency (USEPA). (2002). Calculating upper confidence limits for exposure point concentrations at hazardous waste sites. OSWER 9285.6-10. Washington DC: Office of Emergency and Remedial Response.

[15] De Miguel, E., Iribarren, I., Chacón, E., Ordoñez, A. and Charlesworth, S. (2007). Risk-based evaluation of the exposure of children to trace elements in playgrounds in Madrid (Spain). Chemosphere 66, 505-513.

[16] Lim, H.S., Lee, J.S., Chon, H.T. and Sager, M. (2008). Heavy metal contamination and health risk assessment in the vicinity of the abandoned Songcheon AueAg mine in Korea. Journal of Geochemical Exploration, 96, 223-230.

[17] Farago, M.E. and Kavanagh, P. (1999). Proportions of arsenic species in human urine. In Arsenic Exposure and Health Effects III (pp. 325-334). Elsevier Science Ltd.

[18] Culbard, E. B. and Johnson, L. R. (1984). Elevated arsenic concentrations in house dusts located in a mineralised area of south- west England:mimplication for human health. Trace Substances in Environmental Health. XVIII. University of Missouri, Columbia, 311-319.

[19] Rieuwerts, J. S., Searle, P. and Buck, R. (2006). Bioaccessible arsenic in the home environment in southwest England. Science of the Total Environment, 371(1-3), 89-98.

[20] Daniel, R.S., Michael, J.W., Darren, J.B., Elliot, M.H., Giovanni, S.L., Tony, F., Rebecca, M.C and David, A.P. (2017). Arsenic in residential soil and household dust in Cornwall, South west England: Potential human exposure and the influence of historical mining. Environmental Science Processes and Impacts, 10,1039.

[21] United States Environmental Protection Agency (USEPA). (2017). Regional screening levels- Residential Table Soil. Retrieved from https://www.epa.gov/risk/regional-screening-levels-rsls-generic-tables-june-2017.

[22] California Environment Protection Agency (Ca/EPA) (2005). Use of California human health screening levels (CHHSIs) in evaluation of contaminated properties. California Environmental Protection Agency.

[23] Li, X., Poon, C.S. and Liu, P.S. (2001). Heavy metal contamination of urban soils and street dusts in Hong Kong. Applied Geochemistry 16: 1361-1368.

[24] Al-Khashman, O.A. (2004). Heavy metal distribution in dust, street dust and soils from the work place in Karak Industrial Estate, Jordan. Atmospheric Environment 38: 6803-6812.

[25] Adachi, K. and Tainosho, Y. (2004). Characterization of heavy metal particles embedded in tire dust. Environment International 30: 1009- 1017.

[26] Kurt-Karakus, P.B. (2012). Determination of heavy metals in indoor dust from Istanbul, Turkey: Estimation of the health risk. Environment International, 50, 47-55

[27] Fairus, M.D., Rabiatul, A.N., Siti, M.S., Zitty, S.I. and Nur, A.O. (2010). Heavy metals composition of indoor dust in nursery schools building. Procedia-Social and Behavioral Sciences, 38, 169-175.

[28] Rashed, M. N. (2008). Total and extractable heavy metals in indoor, outdoor and street dust from Aswan City, Egypt. CLEANSoil, Air, Water, 36(10-11), 850-857.

[29] Popoola, O.E., Bamgbose, O., Okonkwo, O.J., Arowolo, T.A., Popoola, A.O. and Awofolu, O.R. (2012). Heavy metals content in classroom dust of some public primary schools in metropolitan Lagos, Nigeria. Research Journal of Environmental and

Earth Sciences, 4 (4), 460-465.

[30] California Environment Protection Agency (Ca/EPA) (2010). California human health screening levels- Residential soil. Office of Environmental Health Hazard Assessment. Retrieved from https://oehha.ca.gov/chhsltable. 
International Journal of Advances in Scientific Research and Engineering (ijasre), Vol 6 (3), March -2020

[31] Mohd, T.L., Saw, M.Y., Azlina, S., Noorlin, M., Nor, H.B., Mazlin, B.M. and Norhayati, M.T. (2013). Composition of heavy metals in indoor dust and their possible exposure in Malaysia. Springer science+BusinessMedia Dordrecht.

[32] Saeed, A. and Seyed, E. (2017). Health risk assessment of heavy metals in indoor dust from Bushehr, Iran. Iranian Journal of Health, Safety and Environment, 5(2), pp. 966-971.

[33] Moya, E. A., Nobili, M. P., Piergrossi, S., Brusati, V. and Moja, E. A. (2004). The effect of patient-centered contraceptive counseling in women who undergo a voluntary termination of pregnancy. Patient Education and Counseling, 65(3),361368.

[34] Olujumi, O., Steiner, O. and Goessler, W. (2015). Pollution indexing and health risk assessments of trace elements in indoor dust from classrooms, living rooms and offices in Ogun State, Nigeria. Journal of African Earth Sciences, 101, 396-404.

[35] Chattopadhyay, G., Lin, K.C. and Feitz, A.J. (2003). Household dust metal levels in the Sydney metropolitan area. Environmental Research 93, 301-307.

[36] Habil, M. and Taneja, A. (2011). Children's exposure to indoor particulate matter in naturally ventilated schools in India. Indoor Built Environment, 20, 430-448.

[37] Habil, M., Massey, D.D. and Taneja, A., (2013). Exposure of children studying in schools of India to PM levels and metal contamination: sources and their identification. Air Quality, Atmosphere \& Health, 6(3), pp.575-587.

[38] Jaradat, Q. M., Massadeh, A. M., Momani, K. A.. and Al Saleem, M. A. (2004). The spatial distribution of Pb, Cd, Zn, and Cu in agricultural roadside soils. Soil and Sediment Contamination, 19(1), 58-71.

[39] Tong, S.T. (1998). Indoor and outdoor household dust contamination in Cincinnati, Ohio, USA. Environmental Geochemistry and Health, 20(3), 123-133.

[40] Turner. A. (2011). Oral bioaccessibility of trace metals in household dust: A review of environmental Geocmistry Health 33: 331 341.

[41] United States Environmental Protection Agency (USEPA). (1984). Drinking water standards and health advisories.Office of Water, Washington, D.C. available at http://www.epa.gov/ost/drinking/standards/dwstandards.pdf.

[42] United States Environmental Protection Agency (USEPA). (2011). Exposure factors handbook 2011 edition. EPA/600/R09/052F. Washington D.C: National Center for Environmental Assessment, Office of Research and Development.

[43] United States Environmental Protection Agency. USEPA (2011). Exposure Factors Handbook, U.S. Environmental Protection Agency, Washington, DC.

[44] Wang, Z., Liu, S., Chen, X. and Lin, C. (2006). Estimates of the exposed dermal surface area of Chinese in view of human health risk assessment. Journal of Safe and Environment, 8 (4), 152-156. 